\title{
GEOLOGIA E GEOQUÍMICA DAS ROCHAS METABÁSICAS DO SUPERGRUPO AÇUNGUI A NORTE DA ZONA DE CISALHAMENTO QUARENTA OITAVA, SUL DO ESTADO DE SÃO PAULO
}

\author{
GEOLOGY AND GEOCHEMISTRY OF METABASIC ROCKS FROM AÇUNGUI SUPERGROUP, \\ NORTH OF QUARENTA OITAVA SHEAR ZONE, SOUTH OF SÃO PAULO STATE \\ Otávio Augusto Ruiz Paccola VIEIRA ${ }^{1}$, Antonio Misson GODOY ${ }^{2}$, George Luiz \\ LUVIZOTTO ${ }^{2}$, Jonas Menezes ZENERO ${ }^{1}$ \\ ${ }^{1}$ Programa de Pós-Graduação em Geociências- IGCE- UNESP- Univ. Estadual Paulista. E-mails: otaviovieirageo@gmail.com, \\ jonaszenero@gmail.com \\ ${ }^{2}$ Departamento de Petrologia e Metalogenia- IGCE- UNESP- Universidade Estadual Paulista. Av. 24A, 1515-Bela Vista. Rio Claro
} (SP), Brasil. E-mails:antonio.godoy@unesp.br, george.luvizotto@unesp.br

\author{
Introdução \\ Materiais e Métodos \\ Geologia Regional \\ Geologia da Área \\ Química Mineral \\ Plagioclásio \\ Anfibólio \\ Metamorfismo \\ Litogeoquímica \\ Conclusões \\ Agradecimentos \\ Referências
}

\begin{abstract}
RESUMO - Rochas ortoderivadas de composição básica e ultrabásica são constituídas por anfibolitos, metabasitos e metaultrabásitos de idade meso a neoproterozoica. Localizam-se no sudoeste do estado de São Paulo, na porção sul do Cinturão Ribeira e norte do Terreno Apiaí. Encontram-se inseridas em rochas da sequência metavulcanossedimentar do Supergrupo Açungui, especificamente na Formação Água Clara e no Grupo Itaiacoca. A paragênese mineral principal é constituída de ferrotschermakita- ferrohornblendamagnesiohornblenda \pm oligoclásio/andesina, representando o ápice do metamorfismo regional progressivo $\mathrm{M}_{1}$, de $611^{\circ} \mathrm{C}$ a $621^{\circ} \mathrm{C}$ de temperatura e 6,5 kbar a 7,3 kbar $( \pm 0,6)$ (Fácies anfibolito médio); e uma paragênese mineral de actinolita/tremolita \pm albita, do retrometamorfismo regional $\mathrm{M}_{3}$ (fácies xisto verde baixo a médio). Dados geoquímicos classificam as rochas como gabro, basanito e picrito, sub alcalinos de baixo potássio a alcalinos, Fe-toleíticos a Mg-toleíticos, com leve tendência a basaltos komatíticos. Já os dados geotectônicos, corroborados pelo comportamento dos elementos traços e dos ETRs, indicam três assinaturas principais para os grupos anfibolíticos: rochas básicas toleíticas a komatiíticas associadas a cadeia mesoceânicas (MORB), com possível interação da crosta na fase de subducção; rochas ultrabásicas alcalinas de ilha oceânica (OIA); e basaltos toleíticos de arco de ilha. Portanto, os eventos magmáticos estão correlacionados ao estágio inicial de abertura de bacia ou ao início de fechamento à fase inicial de natureza toleítica de fundo oceânico, associado a basaltos alcalinos de ilha oceânica.

Palavras-chave: geologia, geoquímica, metabásica, Supergrupo Açungui.
\end{abstract}

\begin{abstract}
Basic and ultrabasic ortho-derived rocks are composed of amphibolites, metabasites and metaultrabasites of meso to neoproterozoic age, are located in the southwest of São Paulo State, in Ribeira Belt southern portion and north of Apiaí Terrain. They are inserted in Supergroup Açungui metavolcanicsedimentary rocks, specifically in Água Clara Formation and Itaiacoca Group. The main mineral paragenesis consists of ferrotschermakite- ferrohornblende- magnesiohornblende \pm oligoclase / andesine, representing the progressive regional metamorphism M1 climax, from $611{ }^{\circ} \mathrm{C}$ to $621{ }^{\circ} \mathrm{C}$ in temperature and $6.5 \mathrm{kbar}$ to $7.3 \mathrm{kbar}( \pm 0,6)(\mathrm{Mid}$ amphibolite facies); and a mineral paragenesis of actinolite / tremolite \pm albite, from M3 regional retrometamorphism (low to mid greenschist facies). Compositional geochemical data classify the rocks as gabbro, basanite and picrite, low potassium sub alkaline to alkaline, Fe-tholeitic to Mg-tholeitic, with a slight tendency to komatiitic basalts. Geotectonic data, corroborated by the behavior of trace elements and REEs, indicate three main signatures for amphibolitic groups: basic tholeitic and komatiitic rocks associated with mid-ocean ridge (MORB), with possible crust interaction in subduction phase; ultrabasic alkaline ocean island rocks (OIA); and island arc tholeiitic basalts. Therefore, magmatism is correlated to the initial stage of opening of the basin or to the beginning of closure, to the initial phase of tholeitic ocean floor nature, associated with ocean island alkaline basalts.

Keywords: geology, geochemistry, metabasic, Açungui Supergroup
\end{abstract}

\section{INTRODUÇÃO}

A região sul-sudoeste do Estado de São Paulo, área do Vale do Ribeira, é de extrema importância geológica no contexto tectônico regional, onde se articula a junção entre os terrenos Apiaí, Curitiba e Luís Alves, separados por importantes zonas de cisalhamento.

Os primeiros trabalhos publicados desta região e proximidades estão voltados para atividades de prospecção pelo Departamento Nacional de Pesquisa Mineral, a partir de 
mapeamento geológico correspondente às regiões da folha topográfica do Instituto Brasileiro de Geografia e Estatística - IBGE, em escala 1:100.000, denominada de Guapiara (SG.22-X-B-II), estudada por Melcher et al. (1971); Cordani et al. (1971); Algarte et al. (1973); Francisconi et al. (1981); Chiodi Filho et al. (1983) e Takahashi et al. (1984).

A geologia da região está definida nos mapas geológicos de integração do estado de São Paulo em escala 1:500.000 elaborado pelo Instituto de Pesquisa Tecnológica-IPT (Bistrichi et al., 1981; Almeida et al., 1981a, Hasui et al., 1981) e no mapa em escala 1: 750.000 elaborado pela Companhia de Pesquisa de Recursos Minerais (Perrotta et al., 2005).

A área geológica de ocorrência das rochas ortoderivadas metabásicas estudadas, insere-se nas folhas topográficas em escala 1:50.000, designadas de Guapiara (SG-22-X-B-II-2), descrita recentemente em Vieira (2017), Vieira et al. (2018a, b) e Capão Bonito (SG-22-X-B-III-1), em Bolonini \& Godoy, 2013; Godoy et al. (2019), além de Ribeirão Branco (SG.22-X-B-II1), em Theodorovicz et al. (1986, 1988).

A área encontra-se localizada a norte da Zona de Cisalhamento Quarenta Oitava, que constitui uma feição morfológica linear de direção geral NE-SW, inserida no polígono constituído pelas cidades homônimas que definem a nomenclatura das folhas topográficas em 1:50.000. Encontra-se limitada pelas coordenadas $24^{\circ} 15^{\prime}$ e $24^{\circ} 00^{\prime}$ de latitude sul e $48^{\circ} 15^{\prime}$ e $49^{\circ} 00^{\prime}$ de longitude oeste (Figura 1).

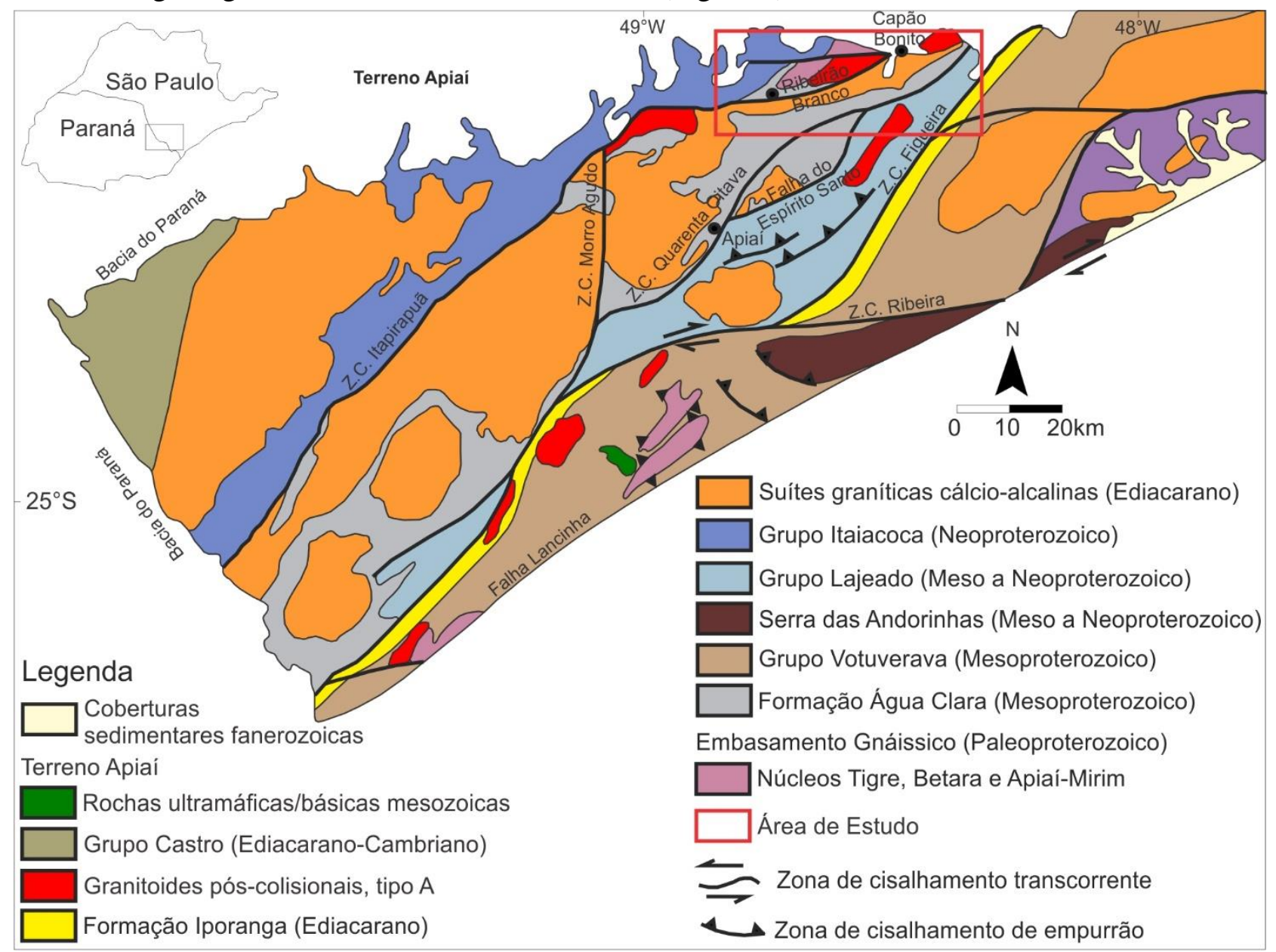

Figura 1- Mapa do Pré-Cambriano dos estados de São Paulo e do Paraná, com a localização da área de estudo em relação à disposição das principais unidades litoestratigráficas. Mod. de Perrotta et al. (2005) e Faleiros (2008).

A região é constituída por rochas epimetamórficas e ígneas da sequência metavulcanossedimentar do Supergrupo Açungui, de idade meso- neoproterozoica (Tassinari et al., 1990; Fiori, 1990, 1992, 1994; Hackspacher \& Godoy, 1999; Hackspacher et al., 2000; Dantas et al. 2000). A divisão estratigráfica proposta para a área define duas unidades litotectônicas principais denominadas de Formação Água Clara (Supergrupo Açunguí) e Grupo Itaiacoca.

As rochas ígneas ácidas neoproterozoicas, cálcio alcalinas sin colisionais, na área, são representadas principalmente pelas rochas do 
Complexo Granítico Três Córregos, além de stocks graníticos do tipo A: Capão Bonito, Campina do Veado e Santa Blandina.

$\mathrm{Na}$ área são reconhecidas as rochas ígneas básicas definidas muitas vezes por uma superposição de lineamentos mesozoicos, orientados na direção principal NW-SE e que marcam importantes feições morfoestruturais regionais. Estas rochas são resultantes da estruturação do Arco de Ponta Grossa, associadas ao magmatismo Serra Geral. Ocorrem também na área rochas sedimentares do Grupo Itararé e sedimentos recentes associados à Bacia do Paraná.

As rochas metamáficas apresentam grande importância pois podem ocorrer de forma preservada, em meio a metassedimentos de baixo grau.

São importantes na determinação de minerais índices que permitam a obtenção de valores numéricos de $\mathrm{P}$ e $\mathrm{T}$ satisfatórios, em detrimento as rochas metassedimentares que frequentemente apresentam associação paragenética complexas na determinação do grau metamórfico, bem como, relações intensas de transformações minerais, pelo elevado grau e estado de intemperismo.

Neste texto são apresentados e discutidos dados de campo, petrográficos, geoquímicos e de química mineral, exclusivamente do orto anfibolito e metabásica da sequência metavulcanossedimentar do Supergrupo Açungui, na unidade da Formação Água Clara, e do Grupo Itaiacoca, com o intuito de estabelecer as relações petrográficas, quanto aos aspectos texturais e temporais e, identificar as paragêneses ígneas e as condições metamórficas, além de evidenciar os sucessivos eventos de deformação e metamorfismo que afetaram este conjunto de rochas.

O estudo petrogenético teve como objetivo identificar as características das fontes magmáticas e entender os processos envolvidos na geração e evolução destes magmas, permitindo identificar e definir as diferentes assinaturas geoquímicas, afinidades tectônicas, gênese e evolução dos magmas metamáficos da região.

\section{MATERIAIS E MÉTODOS}

As amostras de rochas orto anfibolíticas foram analisadas nos laboratórios do Departamento de Petrologia e Metalogenia (DPM) Universidade Estadual Paulista - Unesp de Rio Claro.

A análise química de rocha total e multielementar para elementos maiores, menores, traços e elementos terras raras (ETR), foi realizada no Laboratório de Geoquímica - LABOGEO-Rio Claro, sendo utilizados Fluorescência de Raios X para os elementos maiores (concentração em \%), através de pastilha fundida em meio borato e para os elementos traços (concentração em ppm), através de pastilha prensada. Para a determinação dos elementos de terras raras (ppm) Espectrometria de Emissão Atômica (ICP-AES), segundo rotina do Labogeo (Malagutti et al., 1988).

A análise química qualitativa e semiquantitativa foi realizada em amostras de plagioclásio e anfibólio, bem como imagens de elétrons retro-espalhados (BSE), realizadas no Laboratório de Microscopia Eletrônica do DPM, utilizando-se Microscópico Eletrônico de Varredura (MEV) modelo JEOL-JSM-6010LA, com detector de EDS (Energy Dispersive X-Ray Spectrometer) acoplado.

Análises químicas quantitativas de minerais foram realizadas no Laboratório de Microssonda
Eletrônica do DPM, utilizando-se microssonda eletrônica (EPMA) modelo JEOL JXA8230 Superprobe, com 5 detectores WDS.

Estas análises foram realizadas em lâminas delgadas-polidas recobertas com fina camada de carbono e realizadas sob condições analíticas de 15 a $20 \mathrm{kV}$, com corrente de aceleração de $15 \mathrm{kV}$ em minerais silicáticos formadores de rocha. Para as análises de plagioclásio e anfibólio, utilizou-se tempo de contagem de 10 segundos, no pico, e 5 segundos em cada posição do background (inferior e superior).

A análise química de anfibólio permitiu o estudo para o cálculo de temperatura que foi baseado no trabalho de Otten (1984), utilizando-se o valor de titânio adquirido em análise quantitativa dos cristais de hornblenda, segundo a fórmula:

$$
\mathrm{T}\left({ }^{\circ} \mathrm{C}\right)=1,204 \times(\mathrm{Ti} / 23 \mathrm{O})+545^{\circ}
$$

onde $\mathrm{Ti} / 23 \mathrm{O}$ - representa o número de cátions de Ti por unidade de fórmula (23 oxigênios).

O cálculo da pressão seguiu os parâmetros estabelecidos por Schmidt (1992), que utilizou o alumínio em análise quantitativa de hornblenda, utilizando a fórmula:

$$
\mathrm{P}( \pm 0.6 \mathrm{kbar})=-3,01+4,76 \mathrm{Al}_{\text {tot }}
$$

onde $\mathrm{Al}_{\text {tot }}$ representa o número de cátions de $\mathrm{Al}$ por unidade de fórmula. 


\section{GEOLOGIA REGIONAL}

Os processos sedimentares, tectônicos e metamórficos que configuram a evolução geológica da área mapeada mostram-se intimamente ligados aos eventos atuantes no Terreno Apiaí, durante a Orogênese Brasiliana.

A área insere-se na Província Mantiqueira Central (Almeida, 1967; Hasui \& Oliveira, 1984; Heilbron et al., 2004), na região sul do Cinturão de Dobramentos Sudeste (Cordani et al., 2000), subdividida em grandes compartimentos geotectônicos, na faixa sul do Cinturão Ribeira (Almeida et al., 1977; Cordani et al., 1973; Hasui et al., 1978; Hasui, 2010, 2012).

O Cinturão Ribeira é dominado por terrenos de origens distintas, separados por zonas de cisalhamento (Heilbron et al., 2004; Faleiros, 2008; Faleiros et al., 2011; Santos et al., 2015) e, portanto, a parte sul do cinturão é dividido em dois terrenos, Apiaí e Curitiba, separados pela zona de Falha Lancinha-Cubatão.

Especificamente, a área encontra-se no Terreno Apiaí (Hasui, 2010, 2012), compartimentado e dividido em blocos geotectônicos menores, originados a partir das grandes zonas de cisalhamento destrais que colocaram unidades de idades e profundidades diferentes lado a lado (Campanha, 1991, 2002; Campanha \& Sadowski, 1999; Heilbron et al., 1995, 2004; Faleiros, 2008; Faleiros et al., 2010, 2011; Santos et al., 2015).

O Terreno Apiaí na área é dominado pela unidade metavulcanossedimentar do Supergrupo Açunguí, que teve a sua divisão estratigráfica definida em duas unidades litotectônicas principais denominadas Formação Água Clara e Grupo Itaiacoca.

A Formação Água Clara predomina em toda a área estudada e foi definida originalmente por Marini et al. (1967); Almeida (1984), Almeida et al. (1986), como uma faixa alongada de direção NE-SW, aflorante na região Sul de São Paulo, correspondente a uma sequência carbonática impura, posicionada no topo do Grupo Açungui.

Posteriormente, Fritzons Jr et al. (1982), Bistrichi et al. (1985) e Almeida et al. (1986) interpretam como a formação basal ao Grupo Açungui, inserida no Complexo Setuva. Chiodi Filho et al. (1983), Takahashi et al. (1984) e Theodorovicz et al. (1986) classificam-na como correlata a Formação Itaiacoca, contrariando Fritzons Jr et al. (1982), que a classificaram como correlata a Formação Perau, mas ambas inseridas no Complexo Setuva. Weber (2004) e Weber et al. $(2002,2004)$ a consideram como formação basal ao Supergrupo Açungui no estado de São Paulo.

O primeiro autor a propor uma divisão interna para a Formação Água Clara foi Pontes (1981), subdividindo-a em uma sequência carbonática, nomeada de Fácies São Domingos e numa sequência vulcânica, nomeada de Fácies São Silvestre.

São descritas também sequências terrígenas, originalmente consideradas como basais à essa Formação (Suíte Metamórfica Rio Abaixo Chiodi Filho et al., 1983; Suíte Metamórfica Santana - Takahashi et al., 1984; Formação Setuva - Bistrichi et al., 1985; Xistos Santana Campanha et al., 1987; Complexo Apiaí Mirim Theodorovicz et al., 1988 e Campanha, 1991) e, posteriormente adotadas por Weber (2004), Weber et al. (2002, 2004) e Faleiros et al. (2012) como correspondentes a uma sub unidade basal da Formação Água Clara, nomeada como Membro Xistoso.

Em contrapartida, as unidades propostas por Pontes (1981) são unidas em um único grupo, nomeado de Membro Carbonático, correspondente ao topo da Formação Água Clara.

O Membro Carbonático é formado predominantemente por rochas calciossilicáticas e mármore, apresentando intercalações de meta psamo pelito, metabasíto, anfibólio xisto, metachert e metatufo básico. Já o Membro Xistoso é caracterizado por alternância entre camadas de quartzo-mica xisto, micaxisto, xisto carbonático e subordinadamente camadas de xisto grafitoso, quartzito e granada-biotita xisto.

Almeida et al. (1986) observam a variação do grau metamórfico, de SE para NW, de xisto verde baixo a médio até xisto verde médio a alto. Também descrevem ocorrências de metamorfismo de contato, devido a intrusão do Complexo Granítico Três Córregos e seus granitoides associados.

Devido à alta taxa de deformação, a preservação de estruturas sedimentares primárias nas proximidades das zonas de cisalhamento é baixa, sendo encontradas apenas em locais distantes das mesmas (Campanha, 1991; Faleiros et al., 2012).

A Formação Água Clara está possivelmente 
relacionada a um ambiente de sedimentação de águas normalmente rasas, associado a uma plataforma continental, com vulcanismo básico, raramente ácido (Fiori, 1990). Bistrichi et al. 1985; Fassbinder, 1996; Weber et al. (2004) propõe idades Mesoproterozoicas, em torno de 1590-1470 Ma (U-Pb), para a deposição dessas sequências. Os mesmos autores indicam a idade de metamorfismo como neoproterozoica (aproximadamente $600 \mathrm{Ma}$ ).

Campanha (1991, 2002) considera que os contatos entre a Formação Água Clara e os outros metassedimentos se dão em geral por zonas de cisalhamento transcorrente. Já entre a Formação Água Clara e o Complexo Granítico Três Córregos mostram-se imbricados através de zonas de cisalhamento dúcteis de baixo ângulo.

O Grupo Itaiacoca descrito em Bistrichi et al. (1985) e Reis Neto (1994) é constituído por duas sequências sedimentares, uma terrígena e outra química. As rochas do grupo pertencem a uma faixa NW, denominada "Faixa Itapeva" por Hasui et al. (1984), ou "Faixa Itaiacoca-Itapeva" por Chiodi Filho (1984), separada da Faixa Apiaí.

Já no estado de São Paulo, em mapeamento na escala 1:50.000 ao sul de Itapeva, Theodorovicz et al. $(1986,1988)$ confirmaram a presença desta associação metavulcanossedimentar e elevaram a Formação Itaiacoca ao status de grupo, subdividindo-o em três unidades.

Para a região oeste de Ribeirão Branco, Siga Jr et al. (2003) permitiram reconhecer três unidades geológicas maiores, representadas, da base para o topo, por metarcóseo (com importante contribuição vulcânicavulcanoclástica), rochas metacarbonáticas $\mathrm{e}$ rochas metapelíticas-metapsamíticas

$\mathrm{O}$ estudo das rochas metamáficas em sequência metavulcanossedimentar apresenta grande importância na evolução geocronológica e geotectônica destas áreas, o que é observado nos trabalhos sobre as rochas metamáficas, que são enumerados abaixo, de quatro áreas regionais (Formação Água Clara, do Grupo Votuverava, do Metagabro de Apiaí, inserido no Grupo Lajeado e do Grupo Itaiacoca) na Sequência Vulcanossedimentar do Supergrupo Açungui.

Uma importante área de exposição de rochas metamáficas inseridas em rochas da sequência vulcanossedimentar da Formação Água Clara é a região de Araçaíba- SP, primeiramente estudadas por Frasca et al. (1990), que apontaram dois possíveis eventos magmáticos de natureza toleítica, um correspondendo a basaltos de fundo oceânico transicional ou de arco insular imaturo, e outro associado a basaltos shoshoníticos, indicativos de margem continental ativa.

Os dados analíticos U-Pb (convencional, EMF e SHRIMP), apresentados por Weber (2004) Weber et al. (2004), para as rochas metamáficas, indicam épocas de cristalização dos zircões com valores neoproterozoicos obtidos $(\sim 600 \mathrm{Ma})$ (Tabela 1) e provavelmente referem-se a processos de recristalização e neoformação de zircões nas rochas metabásicas.

As características geoquímicas sugerem composições semelhantes a basaltos enriquecidos de cadeias mesoceânicas (EMORB) com tendências a basaltos de ilhas oceânicas (OIB), o que permite sugerir como situação geotectônica geradora deste magmatismo básico, ambientes distensivos ou em bacias de retroarco.

Estudos litogeoquímicos realizados nas rochas metabásicas pertencentes à Formação Água Clara, sugerem para estas rochas origem ortoderivada de natureza toleítica subalcalina, representando basaltos de fundo oceânico transicionais (T-MORB) ou basaltos de arco de ilha (OIB) (Frascá et al., 1990, 1996, 1997; Maniesi, 1997; Maniesi \& Oliveira, 1999; Weber, 2004; e Weber et al., 2002, 2004).

Uma segunda região de importância nos estudos das rochas metamáficas pertencentes ao Supergrupo Açungui, corresponde as regiões de Campo Largo, Rio Branco do Sul e Adrianópolis-PR, relativas ao Grupo Votuverava.

O Grupo Votuverava, segundo Faleiros et al. (2011), apresenta para as rochas metamáficas dados geoquímicos de metabasitos que foram agrupados em três conjuntos apresentando assinaturas toleíticas (G1, G2, G3). O G1 mostra assinatura de arco vulcânico, com razão Ti/V de 15 - 20, enriquecimento em íons litófilos de grande raio iônico (LILE) e empobrecimento em elementos de alta força de campo (HFSE) relativos ao MORB. O padrão dos elementos traços indica importante contribuição do componente de subducção.

O G2 apresenta composição geral semelhante ao MORB, com Ti/V de 22 - 28. Contudo, o comportamento dos elementos traços sugere uma pequena contribuição do componente de subducção. 
O G3 apresenta assinatura de basaltos do tipo MORB enriquecido, com razão $\mathrm{Ti} / \mathrm{V}$ ao redor de 40 e enriquecimento em LILE e HFSE. A variabilidade entre as razões $\mathrm{TiO}_{2} / \mathrm{Yb}$ e $\mathrm{Nb} / \mathrm{Yb}$ sugere que as rochas $\mathrm{G} 1$ e $\mathrm{G} 2$ foram geradas por fusão rasa (fontes mantélicas tipo MORB normal e enriquecido, respectivamente).

As rochas $\mathrm{G} 3$ são enriquecidas em $\mathrm{Ti}$ e $\mathrm{Nb}$, sugerindo interação entre fontes do tipo MORB e pluma. A coexistência de metabasitos, com composições de basaltos toleíticos de arcos vulcânicos e basaltos de dorsais mesoceânicas, sugere um ambiente de sedimentação de bacia retroarco.

Maniesi \& Oliveira (2012) caracterizam os metabasitos da região de Rio Branco do Sul como rochas ortoderivadas, inseridas em rochas metassedimentares proterozoicas do Grupo Votuverava, no estado do Paraná.

São rochas constituídas por uma associação mineral metamórfica com actinolita, hornblenda, albita, epidoto, titanita, quartzo, apatita e opacos, além de clinopiroxênio e hornblenda castanha representantes da mineralogia ígnea parcialmente preservada.

Seus protólitos ígneos possuíam composição de basaltos magnesianos de fundo oceânico com geral empobrecimento em elementos incompatíveis em relação aos basaltos normais de cadeia mesoceânica (N-MORB), exibindo afinidades aos basaltos Komatiíticos.

$\mathrm{Na}$ evolução dos protólitos, a cristalização fracionada teve importante participação, com possível formação de agregados cumuláticos, com predomínio de clinopiroxênio. São metabasitos que podem estar relacionados ao estiramento crustal durante o estágio de abertura da bacia Açungui em tempos proterozoicos.

Maniesi (1997) e Maniesi \& Oliveira (1996, 1998, 1999), apresentam idades K-Ar em concentrado de anfibólio de rochas anfibolíticas de Adrianópolis (675 $\pm 21 \mathrm{Ma}$ ) e de plagioclásios de metabásicas da mesma região $(1456 \pm 25 \mathrm{Ma})$, neste caso em cristais admitidos pelos autores como preservados do metamorfismo.

Apresenta ainda um valor K-Ar em anfibólio de $881 \pm 46 \mathrm{Ma}$, obtido em anfibolitos da região de Campo Largo. Os dados isotópicos obtidos permitiram calcular idades $\mathrm{Sm} / \mathrm{Nd}$ por isócrona mineral, usando rocha total de $820 \pm 84$ Ma para a metabásica de Adrianópolis (Oliveira et al. (2002) (Tabela 1).

Um terceiro caso digno de nota, o Metagabro de Apiaí, inserido no Grupo Lajeado, é composto por clino e ortopiroxênio (augita e hiperstênio) e plagioclásio (andesina/labradorita), com leve alteração hidrotermal, às vezes, com o aparecimento nas bordas do piroxênio de hornblenda, biotita, actinolita e clorita, que se formaram durante o metamorfismo de baixo grau que afetou essa rocha. Ocorre intercalado em um pacote metavulcanossedimentar na Formação Serra da Boa Vista. Segundo Hackspacher et al. (2000), o metagrabo Apiaí, a partir de análise de zircão e monazita, apresenta idades de cristalização de $617 \mathrm{Ma}$.

A assinatura geoquímica é característica de rocha basáltica toleítica subalcalina do tipo EMORB. A assinatura isotópica da rocha metamáfica indica que foram derivadas em parte do manto astenosférico (consistente com a colocação em um ambiente extensivo).

Segundo Oliveira et al. (2012), a idade das rochas do corpo de metagabro apresentam valores neoproterozoicos de $839 \pm 85 \mathrm{Ma}(\mathrm{Rb} / \mathrm{Sr}$ em rocha total) e idades $\mathrm{Sm} / \mathrm{Nd}$ de $885 \pm 53 \mathrm{Ma}$ (Tabela 1) e estão sendo tentativamente interpretados como uma estimativa da época de extração do manto do magma gerador.

As características geoquímicas da maioria das amostras apresentam semelhanças do padrão MORB, em direção ao manto enriquecido e/ou domínio de contaminação crustal constituindo modificações causadas por processos metamórficos, de contaminação crustal e/ou de alteração (Maniesi et al., 1999, Oliveira et al., 2002). Os estudos de termobarometria do metagabro Apiaí, realizados por Oliveira et al. (2012) de piroxênio e plagioclásio, revelam temperaturas de cristalização entre 924 e $1241^{\circ} \mathrm{C}$. Temperaturas menores foram obtidas para $\mathrm{Mg}$ hornblenda e situam-se entre 776 e $927^{\circ} \mathrm{C}$.

A pressão de cristalização foi calculada e está em torno de 3,2 a 4,5 kbar. Os parâmetros retrometamórficos, obtidos em função da presença de actinolita e clorita, indicam temperaturas entre 420 e $484^{\circ} \mathrm{C}$.

Campanha et al. (2015) apresentam para as rochas do Metagabro Apiaí idade de cristalização de $877 \pm 8$ Ma (Tabela 1) para zircões magmáticos e estas rochas representam o magmatismo toleítico semelhante ao MORB, relacionado com a ruptura inicial de um continente mesoproterozoico e a formação do oceano Brasiliano.

Para as rochas do Grupo Itaiacoca, da região 
de Ribeirão Branco-Itararé, segundo Siga Jr et al. (2003), as análises geocronológicas U-Pb realizadas em zircões de dois afloramentos de rochas metavulcânicas, forneceram idades de $628 \pm 18 \mathrm{Ma}$ (SHRIMP) e $636 \pm 30 \mathrm{Ma}$ (convencional). O metamorfismo dessas rochas parece ter ocorrido em épocas bastante próximas $(628$ - $610 \mathrm{Ma})$ à cristalização dos zircões, sugerindo curto intervalo de tempo entre o vulcanismo estudado e os episódios de fechamento da bacia.

Tal padrão isotópico caracteriza um cenário tectônico Neoproterozoico envolvendo vulcanismo, metamorfismo e plutonismo granítico Três Córregos $(630 \quad \mathrm{Ma})$ e Cunhaporanga (590 Ma), interpretados como relativos aos estágios finais da evolução da Bacia Itaiacoca. Reis Neto (1994) apresenta na região de Abapã-PR idades isocrônicas $\mathrm{Rb}-\mathrm{Sr}$ de metavulcânicas ( 1250 Ma) do Grupo Itaiacoca. Interpreta tais valores como relacionados à época de sedimentação/vulcanismo associado à formação dessa bacia (Tabela 1).
Frascá et al. (1990), para a região do Alto e Médio Vale do Ribeira, estudada no trecho entre Apiaí, Iporanga e Barra do Turvo no Estado de São Paulo, sugerem para as metamáficas estudadas três tipos de magmatismo básico durante períodos tectônicos; um de natureza toleítica de estágio inicial de abertura de bacia ou ao início de fechamento; o segundo, basaltos shoshoníticos de margem continental ativa (estágio final de fechamento da bacia) e o terceiro um magmatismo básico toleítico de natureza continental.

Frasca et al. (1996, 1997) para esta região separa as rochas em dois grupos: um a norte do Lineamento Ribeira, constituído por actinolita anfibolito, relativamente enriquecido em $\mathrm{Ca}$ e $\mathrm{Al}$ e pobre em $\mathrm{P}, \mathrm{Ti}, \mathrm{Zr}$, Y e $\mathrm{Sr}$ e semelhantes aos basaltos de arcos de ilhas modernos; e outro a sul do Lineamento Ribeira constituído por hornblenda anfibolito, incluído o metagabro Apiaí que é relativamente enriquecido em $\mathrm{Na}, \mathrm{Fe}$, $\mathrm{Ti}, \mathrm{Zr}, \mathrm{Y}$ e Sr, guardando semelhanças com basaltos de cadeias mesoceânicas modernas.

Tabela 1 - Dados isotópicos de rochas básica da Faixa Ribeira.

\begin{tabular}{|c|c|c|}
\hline \multicolumn{3}{|c|}{ FAIXA RIBEIRA } \\
\hline Grupo Itaiacoca & \multicolumn{2}{|c|}{ Grupo Açungui } \\
\hline Faixa Norte - Ribeirão Branco & Faixa Central - Apiaí-Araçaíba & Faixa Sul - \\
\hline Metavulcânicas & Metagabros & Metabásicas \\
\hline \multirow[t]{3}{*}{$\begin{array}{c}\text { (U-Pb - zircões (Siga Jr et al., 2003) } \\
628 \pm 18 \mathrm{Ma} \text { (SHRIMP) } \\
636 \pm 30 \mathrm{Ma} \text { (convencional). }\end{array}$} & $\begin{array}{c}\text { Grupo Lajeado } \\
\text { (U-Pb - zircão e monazita } \\
\text { (Hackspacher et al., 2000) } \\
617 \pm 4 \text { Ma e } 612 \pm 21 \mathrm{Ma}\end{array}$ & $\begin{array}{c}\text { Grupo Setuba - Abapã } \\
\mathrm{Rb}-\mathrm{Sr}-(\text { Reis Neto, 1994) 1250 Ma) }\end{array}$ \\
\hline & $\begin{array}{c}\text { (Oliveira et al., 2012) } \\
839 \pm 85 \mathrm{Ma}(\mathrm{Rb} / \mathrm{Sr} \text { rocha total }) \\
\mathrm{Sm} / \mathrm{Nd} \text { de } 885 \pm 53 \mathrm{Ma}\end{array}$ & $\begin{array}{c}\text { Adrianópolis - Formação Votuverava } \\
\text { (Maniesi, 1997) K-Ar anfibólio } \\
675 \pm 21 \text { Ma e } 881 \pm 46 \mathrm{Ma} \\
\text { Sm/Nd rocha total, de } 820 \pm 84 \mathrm{Ma}\end{array}$ \\
\hline & $\begin{array}{c}(\mathrm{U}-\mathrm{Pb}-\text { Zircões })(\text { Campanha et al., } \\
2015)-877 \pm 8 \mathrm{Ma}\end{array}$ & $\begin{array}{c}\text { Formação Água Clara } \\
\text { (Weber et al., 2004) U-Pb - Zircões - } \\
(\sim 600 \mathrm{Ma})\end{array}$ \\
\hline
\end{tabular}

\section{GEOLOGIA LOCAL}

As rochas metabásicas foram identificadas e individualizadas a partir de mapeamentos geológicos na escala de 1:50.000 das áreas das folhas topográficas de Guapiara, Capão Bonito e Ribeirão Branco, estendendo-se ao longo de uma faixa descontínua, normalmente com dimensões longitudinais expressivas, quilométricas e, com dimensões laterais de dezenas de metros.

Os metabasitos estudados estão localizados nas proximidades, a norte e a sul da zona de Cisalhamento Itapirapuã (Figura 2). A área de estudo é caracterizada por rochas da Sequência Metavulcanossedimentar do Supergrupo
Açungui, que contêm numerosas intercalações de rochas metamáficas, atribuídas ao metamorfismo de rochas basálticas distribuídos na direção regional geral NE-SW, com fragmentos deformados e dispersos em uma estreita faixa.

A área com maiores ocorrências é caracterizada pela Formação Água Clara definida a norte da Zona de Cisalhamento Quarenta Oitava e a sul da Zona de Cisalhamento Itapirapuã e a segunda área das ocorrências são rochas metabásicas e metaultramáficas inseridas nas rochas do Grupo Itaiacoca, a norte da Zona de Cisalhamento Itapirapuã. 


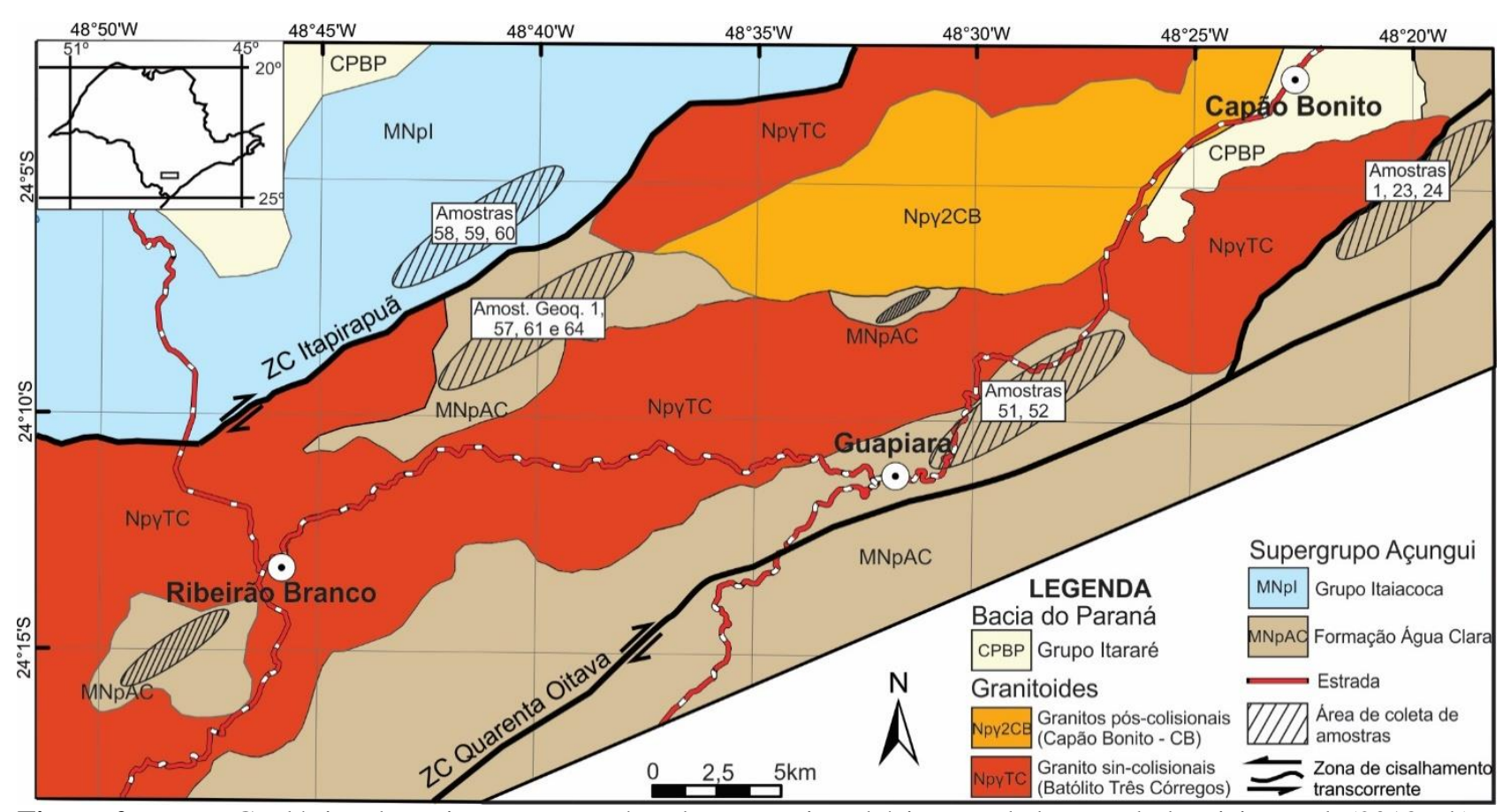

Figura 2 - Mapa Geológico da região com as rochas de composição básica estudadas. Mod. de Vieira et al. (2018a, b) e Godoy et al (2019).

A Formação Água Clara é constituída predominantemente por uma sequência de rochas carbonáticas, mármore puro a impuro, rochas calciossilicáticas, cálcio xisto; uma sequência de rochas terrígenas constituídas por mica xisto, quartzito e clorita-biotita xisto; e rochas da sequência básicas, além de rochas de metamorfismo de contato.

Geomorfologicamente, esta unidade ocorre como morrotes arredondados de textura mais lisa (Figura 3A), ou localmente como corpos dispersos, com dimensões reduzidas e restritas, na forma de corpos tabulares centimétricos a métricos, resultantes de processos deformacionais de estiramento e na forma de pequenas lentes disruptas em meio às rochas metassedimentares, concordantes com a foliação.

As relações de contato dos litotipos metabásicos dificilmente são observadas e, quando presentes, mostram-se concordantes e bruscas com a estruturação das rochas encaixantes.

Apresentam-se quando frescas com cor escura e granulação fina a fina-média, raramente grossa e quando intemperizadas assumem cores verde clara a ocre.

Os corpos de rochas metamáficas mostram-se, por vezes, totalmente anfibolitizados (hornblenda anfibolito), parcialmente transformado por minerais hidratados (clorita + actnolita + epidoto), coerentes com o padrão metamórfico das sequências metassedimentares encaixantes. Os maiores corpos de termos anfibolíticos apresentam textura granoblástica (Figura 3B) a granonematoblástica e nematoblástica, com intensidades de anisotropia variada (Figuras 3C e D), e constituído pela mineralogia essencial de hornblenda e rara actinolita, clorita, epidoto, albita e quartzo, além de raros cristais de pseudomorfos intensamente saussuritizados de oligoclásio, andesina e labradorita, e como minerais acessórios, zoisita, clinozoisita, titanita, zircão, allanita, apatita e minerais opacos.

Nas rochas com menos deformação é possível identificar feições ígneas reliquiares marcadas por cristais ripiformes de plagioclásio, que estão imersos em uma matriz equigranular fina, de coloração cinza escuro; e características ígneas reliquiares magmáticas, como por exemplo, texturas ofíticas a subofítica

As rochas metassedimentares da Formação Itaiacoca são constituídas por lentes de metaultramáfica (Figura 3E) compostas por clorita-tremolita xisto e rochas metabásicas constituídas por epidoto-actinolita-clorita xisto (Figura 3F). Compreende lentes de variadas dimensões, desde métricas a centimétricas, intercalados com as rochas metassedimentares.

Os termos metabásicos são caracterizados por actinolita anfibolito que normalmente transicionam para clorita-actinolita, xisto onde basicamente superpõem uma foliação marcante. Os termos metabásicos apresentam 
características ígneas reliquiares, como por exemplo, texturas ofíticas a subofíticas e minerais pseudomórficos. É dominado por uma mineralogia hidratada como epidoto, clorita e actinolita fibrosa ou fibroradiada, carbonatos, biotita, albita, raros cristais de quartzo e plagioclásio, além de minerais opacos, acessórios e secundários.

As rochas metaultramáficas caracterizam-se por tipos completamente metamorfizados e são constituídas dominantemente por talco-clorita- tremolita xisto. As rochas encontram-se fortemente deformadas desenvolvendo estrutura xistosa. Quando menos deformadas, observa-se estrutura de pillow lava parcialmente preservadas (Figura 3F). As rochas são constituídas principalmente por paragêneses metamórficas hidratadas caracterizadas por tremolita serpentina e talco e em volumes menores de clorita, carbonato, além dos minerais opacos e minerais acessórios comuns as rochas básicas a ultrabásicas.

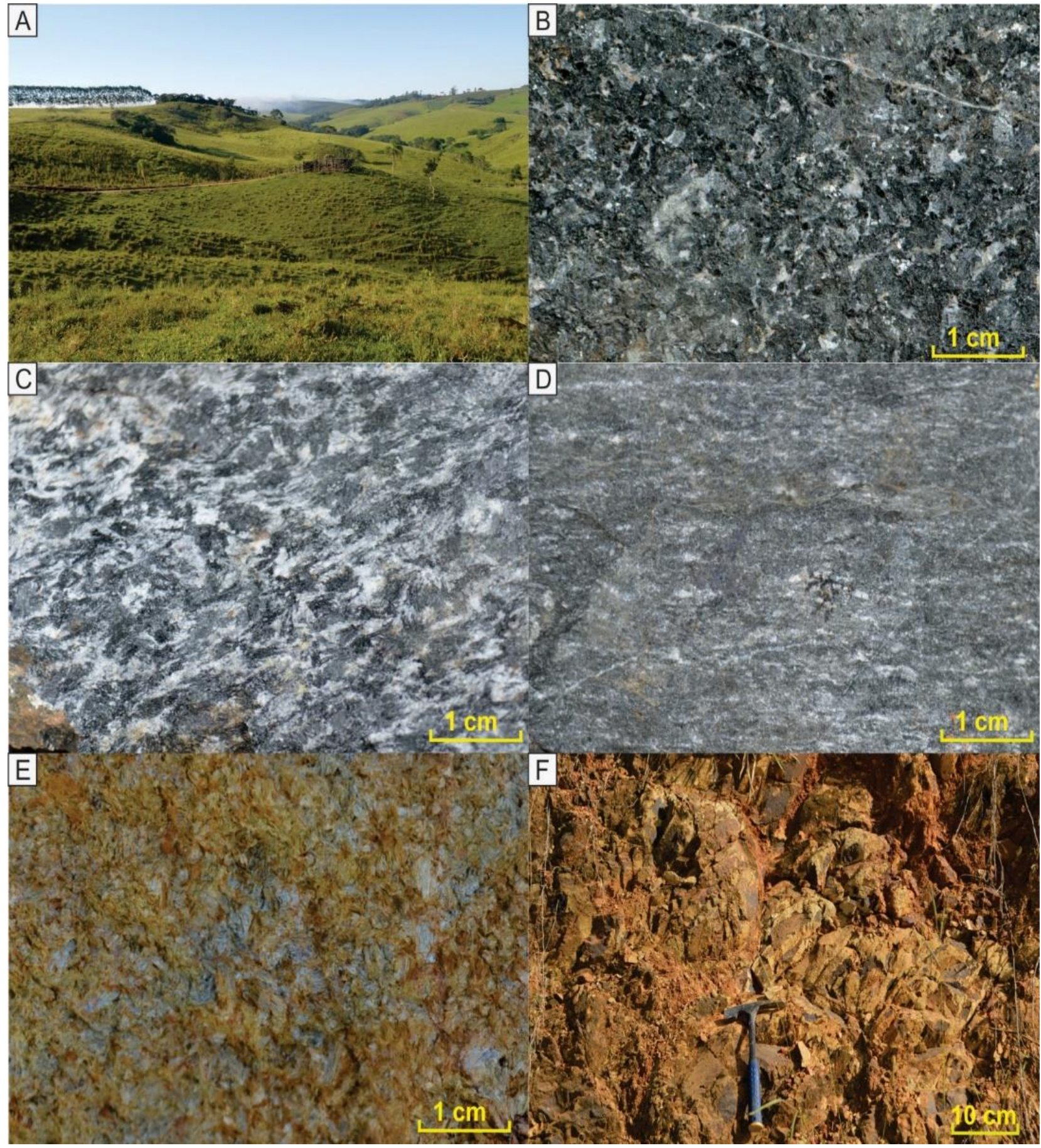

Figura 3 - Fotografias da geomorfologia e dos principais tipos petrográficos anfibolíticos: A) Destaque geomorfológico dos anfibolitos; B) Anfibolito médio a grosso, cinza esverdeado, de estrutura isotrópica; C) Anfibolito médio a grosso, branco esverdeado, de estrutura anisotrópica xistosa; D) Anfibolito fino, cinza esverdeado, de estrutura anisotrópica xistosa; E) Talco-tremolita/actinolita xisto alterado; F) Afloramento com estrutura do tipo pillow lava. 
A evolução geológica para este conjunto de rochas é determinada por três fases principais de deformação identificadas principalmente nas rochas epimetamórficas meso-neoproterozoicas do Supergrupo Açungui.

As estruturas primárias nas rochas metamáficas são de difícil reconhecimento, mas algumas lentes ou corpos encontram-se paralelizadas ao acamamento gradacional reliquiar $\mathrm{S}_{0}$, nas áreas menos deformadas.

Os dois eventos iniciais $\mathrm{D}_{1 / 2}$ são relacionados a uma tectônica tangencial, ligada à fase colisional, progressivos, que se encontram associados às zonas de cavalgamento com formação de dobras isoclinais a recumbentes, a colocação e deformação das rochas graníticas sin- colisionais e a geração de porfiroblastos nas auréolas de metamorfismo de contato desenvolvidas lateralmente aos corpos ígneos.

A fase extensional é caracterizada pela deformação de caráter dúctil-rúptil e retrometamórfica $\mathrm{D}_{3}$ associada à ascensão magmática tardia e a atual estruturação alongada dos granitos pós-colisionais.

Nas zonas de cisalhamento, ocorre a geração de filonito e milonito com acamamento tectônico que oblitera estruturas reliquiares das rochas encaixantes.

\section{PETROGRAFIA}

Os termos básicos são constituídos dominantemente por rochas anfibolíticas e metabásicas e apresentam estrutura marcadamente linear ou xistosa, textura granoblástica a granonematoblástica e nematoblástica, granulação fina a média e um bandamento composicional incipiente formado pela maior concentração de plagioclásio e quartzo em camadas milimétricas descontínuas, alternadas com camadas ricas em hornblenda (Figura 4 A).

Paralelamente ao bandamento, ocorre uma foliação definida pela orientação dos agregados de hornblenda ou por minerais fibrosos de actinolita, clorita e epidoto, quando retrometamorfisada. Localmente, as feições deformacionais milonítica são marcantes.

Os termos metabásicos normalmente apresentam características ígneas reliquiares, como por exemplo, texturas ofíticas a subofíticas (Figura 4 B), além de pseudomorfos parcialmente preservados de augita, intensamente uralitizados e labradorita-andesina, normalmente saussuritizadas

A mineralogia é marcada por anfibólio (hornblenda - actinolita), geralmente alterado para biotita e/ou clorita (Figura $4 \mathrm{C}$ ), o plagioclásio metamórfico (albita/oligoclásio) geralmente saussuritizado (Figura $4 \mathrm{E}$ ), e em maior ou menor proporção, quartzo em torno de $5 \%$ e rara granada, além dos minerais acessórios como titanita, zircão, apatita e minerais opacos. Os minerais secundários são marcados pela presença de carbonato, talco, sericita, epidoto, clinozoisita, leucoxênio, hidróxidos e demais minerais opacos.

No geral, estas rochas são constituídas por $\pm 40 \%$ de hornblenda (Figura $4 \mathrm{~B}$ ), $\pm 30 \%$ de plagioclásio, $\pm 10 \%$ de actinolita/tremolita, $\pm 5 \%$ de quartzo, $\pm 4 \%$ minerais opacos, $\pm 3 \%$ de clorita, $\pm 3 \%$ de biotita, $\pm 3 \%$ de epidoto e $\pm 2 \%$ de minerais acessórios.

$\mathrm{O}$ talco-tremolita/actinolita xisto (Figuras $4 \mathrm{E}$ e $4 \mathrm{~F}$ ) é constituído por hornblenda parcialmente ou totalmente cloritizada/biotitizada, actinolita/tremolita, talco, que originam agregados reliquiares de minerais microcristalinos verdes, e raros grãos de quartzo e plagioclásio. Os minerais acessórios são constituídos por apatita, titanita e leucoxênio. Estas rochas são constituídas por $\pm 70 \%$ de tremolita/actinolita, $\pm 10 \%$ de talco, $\pm 9 \%$ de clorita, $\pm 7 \%$ de epidoto, $\pm 2 \%$ de biotita, $\pm 1 \%$ de titanita, traços de quartzo, apatita e leucoxênio.

O plagioclásio constitui raros pseudomorfos de andesina/labradorita, distribui-se na forma de cristais de hábito tabular. De modo geral, apresenta-se intensamente saussuritizado com geração de diminutos, mas frequentes, cristais de epidoto, sericita e carbonato. O epidoto também ocorre em prismas curtos, bem cristalizados e incolores.

O anfibólio constituído por actinolitatremolita (Figura $4 \mathrm{E}$ ), além de clorita (Figura 4 F) define estrutura isotrópica, sem orientação preferencial visível dos minerais e, secundariamente, estrutura fortemente anisotrópica, marcada pela orientação do anfibólio, normalmente nematoblástica, constituindo uma xistosidade fina ou média a grossa. Localmente, são encontrados tremolitito e/ou talco-tremolita/actinolita xisto, de estrutura anisotrópica fina a média, marcada pela orientação da tremolita/actinolita. 


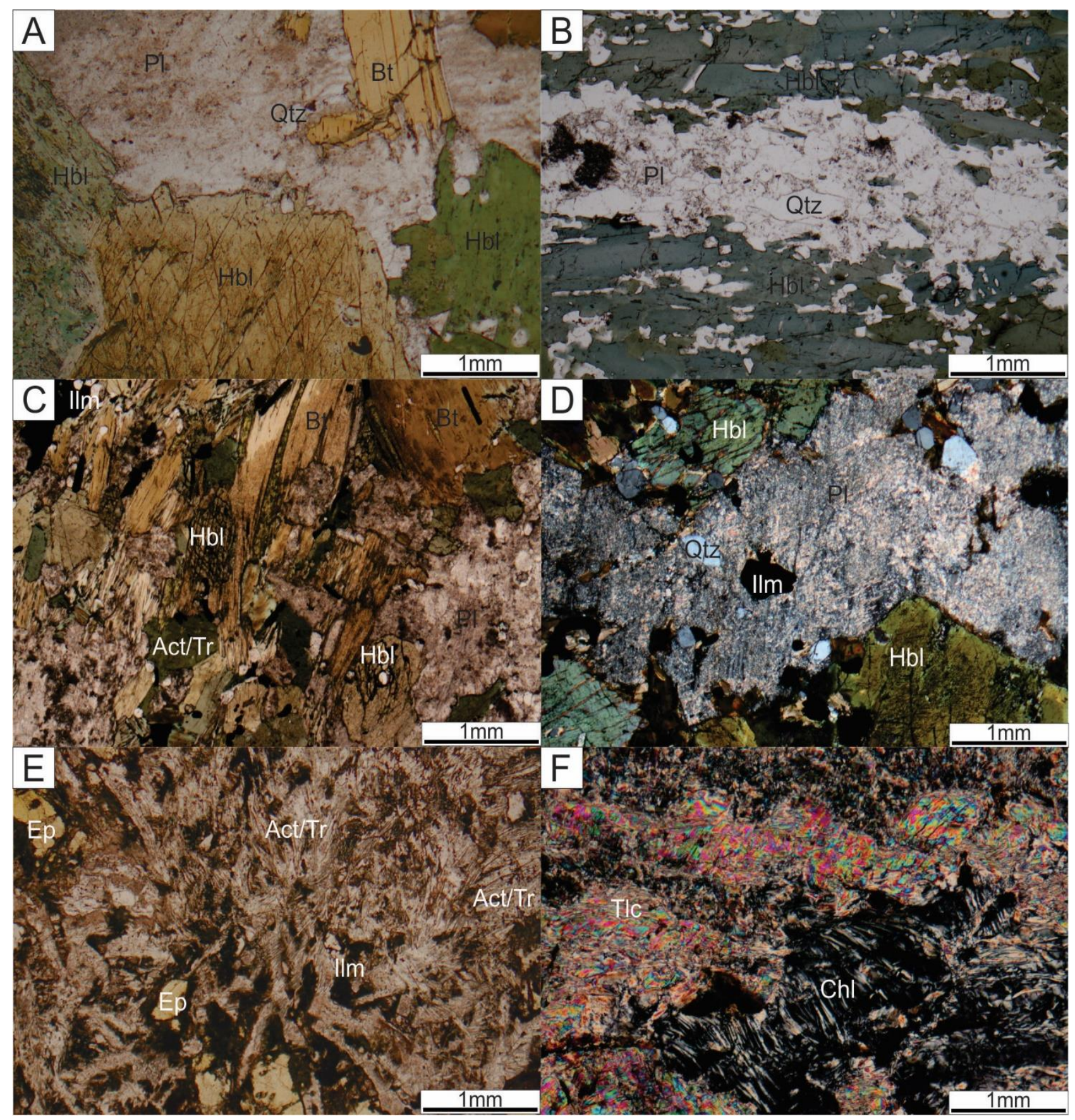

Figura 4 - Fotografias dos principais tipos petrográficos anfibolíticos: Legenda: Fotomicrografia de seção delgada: A) anfibolito médio a grosso anisotrópico; B) anfibolito médio a grosso isotrópico; C) anfibolito fino isotrópico altamente epidotizado e cloritizado; D) Processos de intensa uralitização, biotitização e cloritização em hornblenda; E) Processos de saussuritização e sericitização em plagioclásio; F) clorita-talco-tremolita xisto. Ilm- Ilmenita; Chl- Clorita; HblHornblenda; Bt- biotita; Pl- plagioclásio; Act/Tr- Actinolita/Tremolita; Tlc- Talco; Qtz- Quartzo.

\section{QUÍMICA MINERAL}

$\mathrm{O}$ estudo de química mineral da sequência anfibolítica foi desenvolvido nos principais minerais formadores da paragênese metamórfica e pseudomorfos da paragênese ígnea, como plagioclásio cálcicos intensamente saussuritizados e piroxênios fortemente uralitizados.

Quando parcialmente substituídos, observa-se principalmente processos de hidratação em condições metamórficas de fácies xisto verde média, apresentando as bordas da hornblenda substituídas por actinolita/tremolita, biotita e clorita, e, nas bordas dos cristais de plagioclásio, observa-se processos de recristalização de plagioclásio sódico e saussurita.

Os principais minerais essenciais caracterizados nestas rochas referem-se a cristais de anfibólio (hornblenda) e plagioclásio, que se apresenta como labradorita, quando reliquiar da rocha magmática, oligoclásio/andesina para os 
cristais metamorfisados no ápice metamórfico e albita, gerada durante o retrometamorfismo.

\section{Feldspato}

Os resultados com a composição química do feldspato e o cálculo da fórmula estrutural realizado na base de 32 oxigênios, podem ser vistos na tabela 2 .

Os dados foram projetados no diagrama OrAb-An (Figura 5), dos quais foram obtidas as composições dos cristais de plagioclásio analisados apresentando variações composicionais em três principais grupos, com teor de anortita entre $\mathrm{An}_{49,16}$ - An 65,76 (Cristal reliquiar); $A n_{21,30}-\mathrm{An}_{35,02}$ (Núcleo do cristal); e $\mathrm{An}_{1,52}-\mathrm{An}_{7,65}$ (Bordas e/ou planos de fraqueza) (Tabela 2), predominando composições entre os campos de albita e labradorita (Figura 5).
O primeiro grupo corresponde a cristais de labradorita, sem zoneamento químico e que remetem a pseudomorfos ígneos das rochas básicas.

$\mathrm{O}$ segundo grupo tem como predominante a composição de oligoclásio/andesina, representando o ápice metamórfico da rocha, normalmente acompanhado dos cristais de hornblenda.

O terceiro grupo é representado pela albita, ocorrendo nas bordas e/ou planos de fraqueza de alguns grãos de andesina/labradorita ou raramente como pequenos grãos dispersos na matriz, fortemente identificada e associada, conjuntamente com a clorita, epidoto e actinolita/tremolita, ao metamorfismo regional retrometamórfico.

Tabela 2 - Análise química quantitativa média de plagioclásio em microssonda eletrônica.

\begin{tabular}{|c|c|c|c|c|c|c|c|c|c|c|c|c|c|c|c|c|}
\hline \multirow{2}{*}{$\begin{array}{c}\text { Amostra } \\
\mathrm{SiO}_{2}\end{array}$} & \multicolumn{5}{|c|}{ Cristal reliquiar } & \multicolumn{11}{|c|}{ Núcleo do cristal } \\
\hline & 50.81 & 53.24 & 53.18 & 54.24 & 54.55 & 59.14 & 59.74 & 59.28 & 59.46 & 59.99 & 59.81 & 61.65 & 61.79 & 61.78 & 61.62 & 62.65 \\
\hline $\mathrm{Al}_{2} \mathbf{O 3}$ & 27.32 & 29.07 & 28.70 & 29.02 & 28.42 & 26.17 & 25.25 & 25.90 & 25.52 & 24.67 & 24.59 & 23.91 & 23.85 & 23.91 & 22.72 & 23.56 \\
\hline $\mathrm{Fe}_{2} \mathrm{O}_{3}$ & 0.05 & 0.10 & 0.16 & 0.06 & 0.10 & 0.05 & 0.11 & 0.03 & 0.13 & 0.11 & 0.07 & 0.10 & 0.12 & 0.09 & 0.17 & 0.13 \\
\hline $\mathrm{BaO}$ & 0.01 & 0.00 & 0.00 & 0.05 & 0.02 & 0.01 & 0.12 & 0.03 & 0.10 & 0.08 & 0.01 & 0.00 & 0.08 & 0.03 & 0.03 & 0.02 \\
\hline $\mathrm{CaO}$ & 14.87 & 10.84 & 10.68 & 10.46 & 9.99 & 7.10 & 6.16 & 7.00 & 6.41 & 5.95 & 5.99 & 4.89 & 4.53 & 5.01 & 4.26 & 4.40 \\
\hline $\mathrm{Na}_{2} \mathrm{O}$ & 4.23 & 5.20 & 5.43 & 5.42 & 5.63 & 7.21 & 7.40 & 7.50 & 7.53 & 7.63 & 7.85 & 8.58 & 8.43 & 8.74 & 8.66 & 8.83 \\
\hline $\mathbf{K}_{2} \mathbf{O}$ & 0.07 & 0.08 & 0.08 & 0.07 & 0.12 & 0.12 & 0.84 & 0.10 & 0.47 & 0.32 & 0.17 & 0.31 & 0.50 & 0.20 & 0.31 & 0.24 \\
\hline Total & 97.36 & 98.53 & 98.23 & 99.33 & 98.85 & 99.79 & 99.61 & 99.84 & 99.63 & 98.74 & 98.49 & 99.44 & 99.31 & 99.76 & 97.78 & 99.83 \\
\hline $\mathbf{S i}$ & 2.39 & 2.44 & 2.44 & 2.46 & 2.48 & 2.64 & 2.68 & 2.65 & 2.66 & 2.70 & 2.70 & 2.75 & 2.76 & 2.75 & 2.79 & 2.78 \\
\hline Al & 1.52 & 1.57 & 1.56 & 1.55 & 1.53 & 1.38 & 1.33 & 1.36 & 1.35 & 1.31 & 1.31 & 1.26 & 1.25 & 1.25 & 1.21 & 1.23 \\
\hline $\mathrm{Fe}$ & 0.00 & 0.00 & 0.01 & 0.00 & 0.00 & 0.00 & 0.00 & 0.00 & 0.00 & 0.00 & 0.00 & 0.00 & 0.00 & 0.00 & 0.01 & 0.00 \\
\hline $\mathbf{B a}$ & 0.00 & 0.00 & 0.00 & 0.00 & 0.00 & 0.00 & 0.00 & 0.00 & 0.00 & 0.00 & 0.00 & 0.00 & 0.00 & 0.00 & 0.00 & 0.00 \\
\hline $\mathrm{Ca}$ & 0.75 & 0.53 & 0.53 & 0.51 & 0.49 & 0.34 & 0.30 & 0.33 & 0.31 & 0.29 & 0.29 & 0.23 & 0.22 & 0.24 & 0.21 & 0.21 \\
\hline $\mathbf{N a}$ & 0.39 & 0.46 & 0.48 & 0.48 & 0.50 & 0.62 & 0.64 & 0.65 & 0.65 & 0.67 & 0.69 & 0.74 & 0.73 & 0.75 & 0.76 & 0.76 \\
\hline $\mathbf{K}$ & 0.00 & 0.00 & 0.00 & 0.00 & 0.01 & 0.01 & 0.05 & 0.01 & 0.03 & 0.02 & 0.01 & 0.02 & 0.03 & 0.01 & 0.02 & 0.01 \\
\hline Soma Cátions & 5.05 & 5.01 & 5.02 & 5.00 & 5.00 & 4.99 & 5.00 & 5.00 & 5.00 & 4.99 & 4.99 & 5.00 & 4.99 & 5.01 & 4.99 & 4.99 \\
\hline $\mathbf{A b}$ & 33.89 & 46.25 & 47.69 & 48.17 & 50.11 & 64.30 & 65.16 & 65.60 & 66.15 & 68.57 & 69.64 & 74.69 & 74.87 & 75.07 & 77.20 & 77.33 \\
\hline Anor & 65.76 & 53.28 & 51.85 & 51.40 & 49.16 & 35.02 & 29.98 & 33.83 & 31.11 & 29.54 & 29.38 & 23.52 & 22.22 & 23.80 & 20.99 & 21.30 \\
\hline Ort & 0.35 & 0.47 & 0.46 & 0.43 & 0.73 & 0.68 & 4.85 & 0.57 & 2.73 & 1.89 & 0.99 & 1.80 & 2.91 & 1.13 & 1.82 & 1.37 \\
\hline
\end{tabular}

Tabela 2 - Análise química quantitativa média de plagioclásio em microssonda eletrônica (continuação).

\begin{tabular}{c|ccccccc}
\hline Amostra & \multicolumn{6}{|c}{ Bordas e/ou planos de fraqueza } \\
\hline $\mathbf{S i O}_{2}$ & 62.13 & 61.93 & 62.79 & 63.60 & 63.34 & 63.54 & 66.24 \\
$\mathbf{A l}_{2} \mathbf{O}_{3}$ & 23.98 & 23.32 & 22.32 & 22.99 & 22.93 & 21.87 & 19.86 \\
$\mathbf{F e}_{2} \mathbf{O}_{3}$ & 0.05 & 0.06 & 0.04 & 0.05 & 0.01 & 0.11 & 0.00 \\
$\mathbf{B a O}$ & 0.05 & 0.03 & 0.00 & 0.00 & 0.00 & 0.02 & 0.02 \\
$\mathbf{C a O}$ & 1.54 & 1.59 & 2.70 & 1.03 & 2.33 & 1.30 & 0.32 \\
$\mathbf{N a}_{2} \mathbf{O}$ & 9.27 & 9.10 & 9.50 & 9.43 & 9.72 & 9.72 & 11.39 \\
$\mathbf{K}_{2} \mathbf{O}$ & 1.51 & 1.37 & 0.27 & 1.50 & 0.41 & 0.93 & 0.03 \\
\hline $\mathbf{T o t a l}$ & 98.57 & 97.42 & 97.64 & 98.60 & 98.74 & 97.49 & 97.87 \\
\hline $\mathbf{S i}$ & 2.79 & 2.81 & 2.83 & 2.84 & 2.82 & 2.87 & 2.96 \\
$\mathbf{A l}$ & 1.27 & 1.25 & 1.19 & 1.21 & 1.21 & 1.16 & 1.05 \\
$\mathbf{F e}$ & 0.00 & 0.00 & 0.00 & 0.00 & 0.00 & 0.00 & 0.00 \\
$\mathbf{B a}$ & 0.00 & 0.00 & 0.00 & 0.00 & 0.00 & 0.00 & 0.00 \\
$\mathbf{C a}$ & 0.07 & 0.08 & 0.13 & 0.05 & 0.11 & 0.06 & 0.02 \\
$\mathbf{N a}$ & 0.81 & 0.80 & 0.83 & 0.82 & 0.84 & 0.85 & 0.99 \\
$\mathbf{K}$ & 0.09 & 0.08 & 0.02 & 0.09 & 0.02 & 0.05 & 0.00 \\
\hline Soma Cátions & 5.02 & 5.01 & 5.00 & 5.00 & 5.00 & 5.00 & 5.01 \\
\hline $\mathbf{A b}$ & 83.42 & 83.63 & 85.08 & 85.86 & 86.19 & 87.94 & 98.29 \\
Anor & 7.65 & 8.07 & 13.36 & 5.19 & 11.44 & 6.53 & 1.52 \\
$\mathbf{O r t}$ & 8.93 & 8.30 & 1.56 & 8.95 & 2.37 & 5.54 & 0.18 \\
\hline & & & & & & & \\
\hline & & & & & & \\
\hline
\end{tabular}




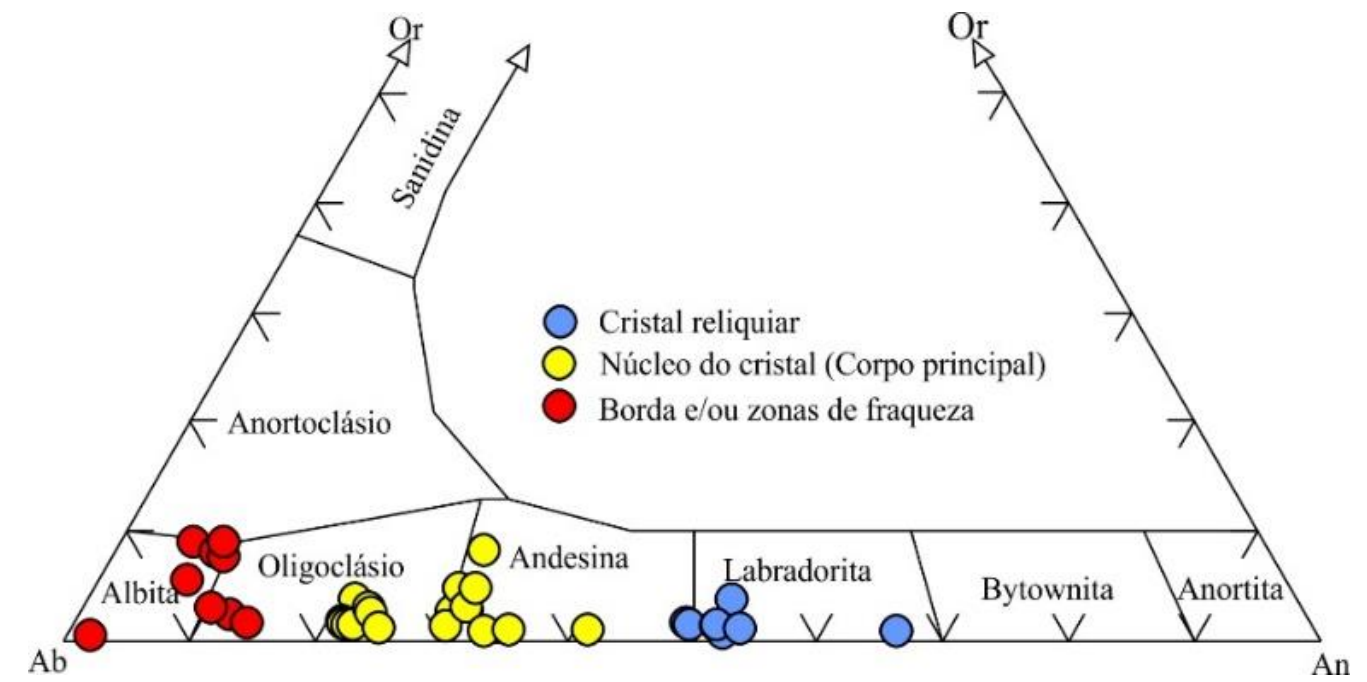

Figura 5 - Diagrama de composição de plagioclásio a partir de valores de K (Or), Na (Ab), Ca (An).

\section{Anfibólio}

Os resultados analíticos, juntamente com a fórmula estrutural aparecem na tabela 3 e na figura 6, sendo o cálculo feito na base de 23 átomos de oxigênio. $\mathrm{O}$ diagrama TSi $\mathrm{x}$ $\mathrm{Mg} / \mathrm{Mg}+\mathrm{Fe}$ de Leake et al. (1977) de classificação dos anfibólios, evidencia a presença de 3 grupos principais: os das rochas básicas com baixa variação da razão $\mathrm{Mg} / \mathrm{Mg}+\mathrm{Fe}(0,4$ a 0,45$)$ e de TSi $(6,2$ a 6,6), entre núcleo e borda (Ferrotschermakita a Ferrohornblenda); os das rochas ultrabásica, sem variação $\mathrm{Mg} / \mathrm{Mg}+\mathrm{Fe}$ $(0,55)$ e baixa variação TSi $(6,4$ a 6,7$)$ entre núcleo e borda (Tschermakita a Magnesiohornblenda); e o grupo das rochas básicas do Grupo Itaiacoca que apresentam alta variação da razão $\mathrm{Mg} / \mathrm{Mg}+\mathrm{Fe}(0,6$ a 0,9$)$ e TSi $(7,0$ a 7,8$)$ entre núcleo e borda
(Magnesiohornblenda a Tremolita).

Relacionando aos eventos metamórficos, essas variações composicionais borda/núcleo são interpretadas, no caso do corpo básico, com o maior número de amostras, como o ápice do metamorfismo regional progressivo, tanto para borda, como para núcleo (Ferrotschermakita a Ferrohornblenda).

Nas rochas ultrabásicas, o núcleo representa cristais reliquiares de anfibólio ígneo (Tschermakita) e a borda, o ápice metamórfico regional progressivo (Magnesiohornblenda).

Nas rochas básicas que se encontram associadas ao Grupo Itaiacoca, o núcleo correlaciona ao ápice metamórfico regional progressivo (Magnesiohornblenda) e as bordas, o ápice do metamorfismo regressivo (retrometamorfismo) (Actinolita/Tremolita).

Tabela 3 - Análise química quantitativa média de anfibólio em microssonda eletrônica.

\begin{tabular}{|c|c|c|c|c|c|c|c|c|c|c|c|c|c|c|c|}
\hline \multirow{3}{*}{ Amostras } & \multicolumn{10}{|c|}{ Rochas Principais } & \multirow{2}{*}{\multicolumn{5}{|c|}{$\begin{array}{c}\text { Ultrabásica } \\
\text { Núcleo do cristal }\end{array}$}} \\
\hline & \multicolumn{5}{|c|}{ Núcleo do cristal } & \multicolumn{5}{|c|}{ Borda do cristal } & & & & & \\
\hline & 64 & 64 & 64 & 64 & 64 & 64 & 64 & 64 & 64 & 64 & 57 & 57 & 57 & 57 & 57 \\
\hline $\mathrm{SiO}_{2}$ & 39.47 & 39.74 & 39.44 & 39.68 & 39.63 & 41.64 & 41.46 & 41.18 & 42.88 & 43.26 & 41.55 & 42.15 & 41.42 & 41.95 & 41.97 \\
\hline $\mathrm{TiO}_{2}$ & 0.48 & 0.49 & 0.50 & 0.44 & 0.49 & 1.73 & 2.05 & 1.88 & 1.02 & 1.28 & 3.74 & 1.61 & 1.86 & 2.20 & 2.08 \\
\hline $\mathrm{Al}_{2} \mathrm{O}_{3}$ & 15.81 & 15.51 & 15.87 & 15.56 & 15.45 & 11.26 & 11.23 & 11.09 & 10.66 & 10.05 & 10.81 & 11.33 & 11.34 & 11.57 & 11.16 \\
\hline $\mathrm{Cr}_{2} \mathrm{O}_{3}$ & 0.04 & 0.01 & 0.02 & 0.00 & 0.02 & 0.01 & 0.00 & 0.01 & 0.03 & 0.02 & 0.02 & 0.02 & 0.02 & 0.01 & 0.01 \\
\hline FeO & 19.84 & 19.38 & 19.41 & 20.04 & 20.30 & 16.09 & 16.15 & 16.35 & 16.13 & 15.68 & 13.43 & 15.08 & 16.01 & 13.67 & 14.63 \\
\hline MnO & 0.30 & 0.29 & 0.33 & 0.32 & 0.28 & 0.24 & 0.25 & 0.26 & 0.20 & 0.24 & 0.19 & 0.18 & 0.19 & 0.17 & 0.19 \\
\hline MgO & 6.04 & 6.59 & 6.24 & 6.14 & 5.98 & 10.35 & 10.30 & 10.26 & 10.83 & 11.33 & 11.93 & 11.21 & 10.56 & 11.70 & 11.00 \\
\hline $\mathrm{CaO}$ & 11.55 & 11.34 & 11.46 & 11.38 & 11.54 & 11.43 & 11.39 & 11.54 & 11.67 & 11.56 & 11.55 & 11.56 & 11.57 & 11.79 & 11.85 \\
\hline $\mathrm{Na}_{2} \mathrm{O}$ & 1.48 & 1.45 & 1.43 & 1.49 & 1.46 & 1.42 & 1.51 & 1.52 & 1.30 & 1.25 & 1.48 & 1.61 & 1.69 & 1.68 & 1.69 \\
\hline $\mathbf{K}_{2} \mathbf{O}$ & 0.48 & 0.42 & 0.41 & 0.40 & 0.39 & 1.00 & 1.05 & 1.04 & 0.80 & 0.78 & 1.22 & 1.29 & 1.17 & 1.08 & 1.08 \\
\hline Total & 95.49 & 95.21 & 95.12 & 95.45 & 95.53 & 95.18 & 95.40 & 95.13 & 95.52 & 95.45 & 95.91 & 96.03 & 95.83 & 95.81 & 95.68 \\
\hline $\mathbf{S i}$ & 6.15 & 6.19 & 6.15 & 6.18 & 6.18 & 6.42 & 6.39 & 6.38 & 6.56 & 6.61 & 6.30 & 6.42 & 6.36 & 6.36 & 6.41 \\
\hline $\mathbf{T i}$ & 0.06 & 0.06 & 0.06 & 0.05 & 0.06 & 0.20 & 0.24 & 0.22 & 0.12 & 0.15 & 0.43 & 0.18 & 0.22 & 0.25 & 0.24 \\
\hline Al & 2.90 & 2.85 & 2.92 & 2.86 & 2.84 & 2.05 & 2.04 & 2.03 & 1.92 & 1.81 & 1.93 & 2.03 & 2.05 & 2.07 & 2.01 \\
\hline $\mathrm{Cr}$ & 0.00 & 0.00 & 0.00 & 0.00 & 0.00 & 0.00 & 0.00 & 0.00 & 0.00 & 0.00 & 0.00 & 0.00 & 0.00 & 0.00 & 0.00 \\
\hline Fe2+ & 2.58 & 2.52 & 2.53 & 2.61 & 2.65 & 2.08 & 2.08 & 2.12 & 2.06 & 2.00 & 1.70 & 1.92 & 2.06 & 1.73 & 1.87 \\
\hline Mn & 0.04 & 0.04 & 0.04 & 0.04 & 0.04 & 0.03 & 0.03 & 0.03 & 0.03 & 0.03 & 0.02 & 0.02 & 0.02 & 0.02 & 0.02 \\
\hline Mg & 1.40 & 1.53 & 1.45 & 1.43 & 1.39 & 2.38 & 2.37 & 2.37 & 2.47 & 2.58 & 2.70 & 2.54 & 2.42 & 2.65 & 2.50 \\
\hline $\mathrm{Ca}$ & 1.93 & 1.89 & 1.92 & 1.90 & 1.93 & 1.89 & 1.88 & 1.92 & 1.91 & 1.89 & 1.88 & 1.89 & 1.90 & 1.92 & 1.94 \\
\hline $\mathbf{N a}$ & 0.45 & 0.44 & 0.43 & 0.45 & 0.44 & 0.43 & 0.45 & 0.46 & 0.39 & 0.37 & 0.44 & 0.47 & 0.50 & 0.49 & 0.50 \\
\hline $\mathbf{K}$ & 0.10 & 0.08 & 0.08 & 0.08 & 0.08 & 0.20 & 0.21 & 0.21 & 0.16 & 0.15 & 0.24 & 0.25 & 0.23 & 0.21 & 0.21 \\
\hline Total & 15.02 & 14.98 & 14.90 & 14.87 & 14.98 & 15.73 & 15.80 & 15.86 & 15.99 & 15.98 & 13.71 & 15.81 & 15.86 & 15.74 & 15.75 \\
\hline
\end{tabular}


Tabela 3 - Análise química quantitativa média de anfibólio em microssonda eletrônica (continuação).

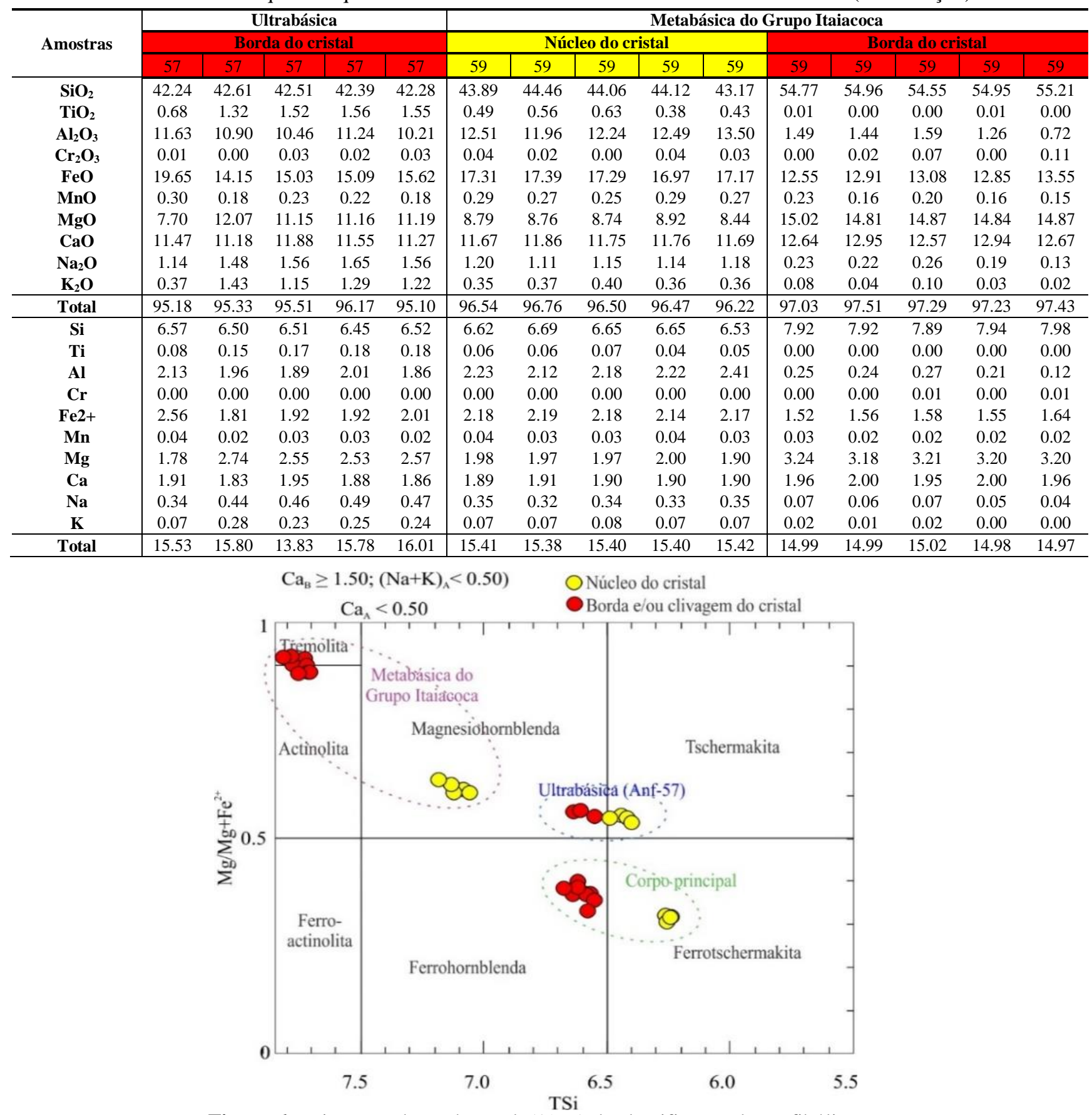

Figura 6 - Diagrama de Leake et al. (1977) de classificação dos anfibólios.

\section{METAMORFISMO}

Os cálculos das condições de $\mathrm{P}$ e $\mathrm{T}$ do metamorfismo nas rochas metamáficas foram feitos a partir das equações propostas por Otten (1984) e Schmidt (1992), respectivamente.

A temperatura foi calculada a partir do titânio adquirido em análise quantitativa dos cristais de anfibólio, segundo a fórmula:

\section{$\mathrm{T}\left({ }^{\circ} \mathrm{C}\right)=1,204 \times(\mathrm{Ti} / 23 \mathrm{O})+545^{\circ}$}

Para tanto, foram utilizados os dados de $\mathrm{Ti}$ médio do núcleo do cristal das rochas básicas e do Grupo Itaiacoca, e da borda do cristal das rochas básicas e das ultrabásicas (Tabela 3), por interpretar-se petrograficamente como o mineral do ápice metamórfico regional progressivo. Outros dados, como, por exemplo, núcleo do cristal de rochas básicas e ultrabásica, foram descartados por considerar-se como cristais reliquiares ígneos, raros pseudomorfos de labradorita e augita e hornblenda. Os valores médios variam entre $604^{\circ} \mathrm{C}$ a $643^{\circ} \mathrm{C}$, com predominância de valores entre $611^{\circ} \mathrm{C}$ a $621^{\circ} \mathrm{C}$.

A pressão foi calculada a partir do alumínio em análise quantitativa de anfibólio, utilizando a fórmula: 
$\mathrm{P}( \pm 0.6 \mathrm{kbar})=-3,01+4,76 \mathrm{Al}_{\text {tot }}$

Utilizou-se primordialmente dados de $\mathrm{Al}$ médio do núcleo e borda do cristal das rochas básicas, ultrabásicas e do grupo Itaiacoca (Tabela 3 ), descartando-se os valores médios dos cristais considerados reliquiares e/ou de retrometamorfismo. O resultado variou entre 5,8 kbar a 7,5 kbar, com predominância de valores entre 6,5 kbar a 7,3 kbar $( \pm 0,6)$.

Caracteriza-se, portanto, como $\mathrm{M}_{1} \mathrm{o}$ evento metamórfico regional progressivo, com paragênese metamórfica na rocha metabásica de ferrotschermakita- ferrohornblenda- magnesiohornblenda \pm oligoclásio/andesina, que, conforme calculado acima, atingiu o pico metamórfico de $611^{\circ} \mathrm{C}$ a $621^{\circ} \mathrm{C}$ de temperatura e 6,5 kbar a 7,3 kbar $( \pm 0,6)$, atingindo o auge desse evento a fácies anfibolito médio.

$\mathrm{O}$ evento metamórfico de contato $\mathrm{M}_{2}$ está associado a colocação de corpos magmáticos ácidos e geração de uma auréola de metamorfismo de contato nas suas bordas. Quando ocorrem junto as rochas metabásicas, observa-se paragênese com granada \pm hornblenda \pm diopsídio \pm andesina/labradorita, caracterizando fácies hornblenda e/ou piroxênio hornfels. As auréolas de metamorfismo termal apresentam-se parcialmente preservadas em razão do menor grau de deformação imposto pelas zonas miloníticas nos contatos destes maciços, ou devido a menor intensidade das transformações minerais retrometamórficas impostas pelo metamorfismo.

$\mathrm{O}$ evento metamórfico dinâmico e retrometamórfico $\mathrm{M}_{3}$ ocorre regionalmente em faixas associados às zonas de cisalhamento de direção NE-SW. O processo é intenso e vinculado à uma foliação milonítica e/ou cataclástica, com desenvolvimento de filonito e um acamamento tectônico que oblitera estruturas reliquiares e as estruturas deformacionais mais antigas, ou mesmo atuam sobre os corpos graníticos, principalmente observado nas suas zonas marginais próximo aos contatos com as rochas metassedimentares e localmente nas regiões internas do corpo por falhamentos direcionais, sempre com direção paralelas às zonas de cisalhamento desenvolvidas no final da fase $\mathrm{D}_{3}$.

Este processo rúptil superpõe o conjunto das rochas, desestabilizando as paragêneses anteriores para condições de fácies xisto-verde baixa a média, a partir de transformações em tremolita/actinolita + clorita + albita.

\section{LITOGEOQUÍMICA}

As análises de rocha total dos litotipos metabásicos e metaultrabásicos encontram-se enumeradas na tabela 4. A distribuição química dos elementos maiores encontra-se caracterizada nos diagramas de Elementos Maiores vs $\mathrm{MgO}$ de Harker (1909).

Foram elaborados diagramas binários utilizando o $\mathrm{MgO}$ como índice de diferenciação (Figuras 7A a $4 \mathrm{H})$. As amostras definem um agrupamento de rochas dominante, de composição básica, com valores bastante homogêneos de sílica, mas distintos em relação ao magnésio e que foram subdividos em três agrupamentos: B1 e B3; B2; B3. No geral, as rochas básicas apresentam entre 45 a $52 \%$ de $\mathrm{SiO}_{2}$, com média ao redor de $50 \%$ e constituem rochas orto anfibolíticas (Tabela 4) inseridas nos litotipos metassedimentares da Formação Água Claras e do Grupo Itaiacoca.

Um segundo agrupamento, com três amostras, apresenta composição ultrabásica com valores entre 43 a $45 \%$ de $\mathrm{SiO} 2$, sendo que, duas amostras de metaultrabásicas estão inseridas nas rochas da Formação Água Clara. Apresentam-se enriquecidas ao redor de $\pm 11 \%$ magnésio, de $\pm 3 \%$ potássio e levemente empobrecida em cálcio $\pm 0,8 \%$, sugerindo pela composição magnesiana, provávelmente uma rocha de composição peridotítica.

Uma das amostras apresenta baixo magnésio $\pm 5 \%$ e potássio $\pm 0,3 \%$ e alto cálcio $21 \%$ e encontra-se inserida em rochas do Grupo Itaiacoca, sugerindo pela composição mais rica em cálcio, provavelmente uma rocha mais rica em piroxênio, derivada de piroxenito.

Observa-se uma normalidade no decréscimo dos teores de $\mathrm{SiO}_{2}, \mathrm{TiO}_{2}, \mathrm{Al}_{2} \mathrm{O}_{3}, \mathrm{Fe}_{2} \mathrm{O}_{3}, \mathrm{CaO}$, $\mathrm{Na}_{2} \mathrm{O}, \mathrm{K}_{2} \mathrm{O}$ e $\mathrm{MnO}$, à medida que o magma é enriquecido em $\mathrm{MgO}$, com exceção as rochas ultrabásicas alcalinas.

A representação de $\mathrm{CaO}$ e $\mathrm{K}_{2} \mathrm{O}$, (Figura 7E, $7 \mathrm{G})$, é de difícil visualização na escala do gráfico, em razão de algumas amostras com valores extremos. Quanto à distribuição binária dos elementos traços vs $\mathrm{MgO}$ dos diagramas das figuras $8 \mathrm{~A}$ a $8 \mathrm{H}$, em relação ao estrôncio $(\mathrm{Sr})$ (Figura 8A), zircônio (Zr) (Figura 8C), ítrio (Y) (Figura 8D), tório (Th) (Figura 8G) e nióbio $(\mathrm{Nb})$ (Figura $8 \mathrm{H}$ ), é visível para a sequência básica ultrabásica uma correlação negativa com o 
crescimento de magnésio das amostras e uma fracionados. No geral, os valores no diagrama de correlação positiva com o aumento de cálcio, bário (Ba) (Figura 8B), níquel (Ni) (Figura 8E) e evidenciando uma associação direta com o cromo $(\mathrm{Cr})$ (Figura $8 \mathrm{~F}$ ) evidenciam um aumento de plagioclásio a partir de magmas mais crescimento associado ao aumento de magnésio.

Tabela 4 - Dados geoquímicos das amostras de para as rochas de composição básica.

\begin{tabular}{|c|c|c|c|c|c|c|c|c|c|c|c|c|}
\hline & Anf 60 & Anf 59 & Anf 58 & Anf 57 & Anf 1a & Anf 51 & Anf 52 & Anf 61 & Anf 1 & Anf 64 & Anf 23 & Anf 24 \\
\hline & \multicolumn{3}{|c|}{ Grupo Itaiacoca } & \multicolumn{9}{|c|}{ Formação Água Clara } \\
\hline & Ultrabásica & \multicolumn{2}{|c|}{ Básica } & \multicolumn{2}{|c|}{ Ultrabásica } & \multicolumn{7}{|c|}{ Básica } \\
\hline & U1 $\square$ & \multicolumn{2}{|c|}{ B1 $\square$} & \multicolumn{2}{|c|}{$\mathrm{U2} \bigcirc$} & \multicolumn{2}{|c|}{ B2 } & \multicolumn{3}{|c|}{ B3 $\bigcirc$} & \multicolumn{2}{|l|}{ B4 } \\
\hline $\mathrm{SiO}_{2}$ & 42,85 & 48,64 & 49,56 & 44,41 & 44,78 & 49,1 & 49,4 & 49,7 & 50,41 & 50,75 & 50,11 & 50,56 \\
\hline $\mathrm{TiO}_{2}$ & 1,15 & 1,15 & 1,12 & 2,06 & 2,03 & 1,73 & 0,77 & 0,71 & 1,09 & 1,18 & 0,34 & 0,55 \\
\hline $\mathbf{A l}_{2} \mathbf{O}_{3}$ & 13,51 & 13,43 & 12,51 & 10,57 & 10,67 & 15,33 & 15,26 & 17,63 & 14,32 & 15,68 & 13,25 & 13,43 \\
\hline $\mathrm{Fe}_{2} \mathrm{O}_{3}$ & 13,76 & 12,41 & 11,35 & 15,51 & 15,21 & 14,27 & 10,75 & 10,69 & 12,56 & 14,11 & 7,68 & 10,18 \\
\hline MnO & 0,21 & 0,13 & 0,16 & 0,16 & 0,16 & 0,17 & 0,16 & 0,15 & 0,18 & 0,18 & 0,15 & 0,19 \\
\hline MgO & 4,8 & 7,06 & 7 & 11,14 & 11,37 & 4,77 & 7,44 & 5,74 & 7,52 & 4,28 & 10,96 & 9,63 \\
\hline $\mathrm{CaO}$ & 21,18 & 11,55 & 12,55 & 9,24 & 8,58 & 10 & 12,25 & 12,35 & 9,06 & 10,64 & 14,41 & 12,53 \\
\hline $\mathrm{Na}_{2} \mathrm{O}$ & 0,2 & 2,99 & 3,41 & 1,23 & 1,33 & 3,45 & 2,09 & 2,23 & 3,18 & 2,43 & 1,21 & 1,83 \\
\hline $\mathrm{K}_{2} \mathrm{O}$ & 0,27 & 0,08 & 0,17 & 2,88 & 2,99 & 0,46 & 0,37 & 0,21 & 0,52 & 0,27 & 0,13 & 0,16 \\
\hline $\mathbf{P}_{2} \mathbf{O}_{5}$ & 0,09 & 0,11 & 0,11 & 0,8 & 0,82 & 0,14 & 0,08 & 0,08 & 0,11 & 0,12 & 0,04 & 0,06 \\
\hline LOI & 2 & 2,45 & 2,09 & 2 & 2,08 & 0,56 & 1,42 & 0,52 & 1,12 & 0,41 & 1,78 & 0,95 \\
\hline Soma & 100,01 & 99,99 & 100,02 & 100,02 & 100,01 & 99,99 & 99,99 & 100 & 100,07 & 100,04 & 100,06 & 100,07 \\
\hline $\mathbf{B a}$ & 59 & 32 & 45 & 1313 & 56 & 34 & 52 & 24 & 1377 & 36 & 45 & 46 \\
\hline Co & 30 & 41 & 60 & 54 & 42 & 37 & 36 & 36 & 53 & 40 & 33 & 43 \\
\hline $\mathrm{Cr}$ & 33 & 112 & 95 & 79 & 45 & 46 & 78 & 73 & 85 & 46 & 93 & 27 \\
\hline $\mathbf{C u}$ & 203 & 150 & 318 & 71 & 182 & 209 & 121 & 118 & 61 & 162 & 36 & 56 \\
\hline $\mathbf{N i}$ & 65 & 133 & 107 & 68 & 68 & 48 & 97 & 73 & 64 & 49 & 134 & 94 \\
\hline Sc & 39 & 37 & 40 & 51 & 43 & 36 & 38 & 36 & 51 & 38 & 44 & 46 \\
\hline $\mathbf{S r}$ & 399 & 149 & 150 & 352 & 194 & 200 & 129 & 108 & 332 & 106 & 101 & 87 \\
\hline $\mathbf{V}$ & 313 & 266 & 302 & 405 & 276 & 364 & 232 & 235 & 391 & 344 & 171 & 210 \\
\hline $\mathbf{Y}$ & 24 & 19 & 20 & 26 & 26 & 30 & 53 & 18 & 27 & 25 & 8 & 12 \\
\hline $\mathbf{N b}$ & 17 & 6 & 6 & 14 & 15 & 7 & 5 & 8 & 5 & 8 & 7 & 6 \\
\hline $\mathbf{Z n}$ & 32 & 88 & 68 & 111 & 101 & 76 & 75 & 65 & 106 & 82 & 44 & 65 \\
\hline $\mathbf{Z r}$ & 17 & 20 & 26 & 41 & 13 & 18 & 11 & 18 & 41 & 26 & 6 & 10 \\
\hline $\mathbf{L a}$ & 3,5 & 4,6 & 4,5 & 21,3 & 5,5 & 12,7 & 13,1 & 3,5 & 22,9 & 6,2 & 1,9 & 2,1 \\
\hline $\mathrm{Ce}$ & 5,9 & 9,2 & 9,1 & 49,1 & 9,8 & 30 & 34 & 6,5 & 52 & 11,7 & 2,2 & 3,9 \\
\hline Pr & 1,15 & 1,44 & 1,36 & 6,74 & 1,71 & 4,11 & 5,05 & 0,95 & 6,93 & 1,55 & 0,31 & 0,51 \\
\hline Nd & 6,7 & 7,5 & 7,3 & 32,5 & 8,5 & 18,9 & 26,7 & 4,8 & 34,7 & 8,1 & 1,6 & 2,7 \\
\hline Sm & 2,2 & 2,1 & 2,6 & 7,5 & 2,3 & 4,5 & 9,2 & 1,7 & 7,7 & 2,6 & 0,6 & 1 \\
\hline Eu & 0,85 & 0,87 & 0,93 & 1,83 & 1,03 & 1,7 & 3,25 & 0,6 & 1,97 & 0,84 & 0,25 & 0,39 \\
\hline Gd & 3,3 & 3,16 & 3,25 & 7,34 & 3,56 & 5,38 & 12,36 & 2,06 & 7,45 & 3,44 & 0,88 & 1,36 \\
\hline $\mathbf{T b}$ & 0,54 & 0,51 & 0,47 & 0,92 & 0,66 & 0,93 & 1,98 & 0,41 & 0,92 & 0,63 & 0,17 & 0,25 \\
\hline Dy & 3,59 & 3,36 & 3,31 & 5,34 & 4,29 & 5,86 & 12,69 & 2,6 & 5,39 & 4,35 & 1,2 & 1,89 \\
\hline Ho & 0,79 & 0,69 & 0,71 & 0,96 & 0,86 & 1,14 & 2,25 & 0,62 & 1 & 0,26 & 0,35 & 0,96 \\
\hline $\mathbf{E r}$ & 2,35 & 2,06 & 1,9 & 2,55 & 2,61 & 3,36 & 6,41 & 1,91 & 2,75 & 0,72 & 1,12 & 2,73 \\
\hline Tm & 0,32 & 0,32 & 0,27 & 0,29 & 0,38 & 0,48 & 0,91 & 0,23 & 0,31 & 0,11 & 0,18 & 0,42 \\
\hline $\mathbf{Y b}$ & 1,9 & 2 & 1,8 & 1,9 & 2,5 & 2,9 & 5,6 & 1,9 & 2,1 & 0,8 & 1 & 2,9 \\
\hline Lu & 0,3 & 0,3 & 0,23 & 0,28 & 0,36 & 0,4 & 0,83 & 0,31 & 0,25 & 0,09 & 0,14 & 0,46 \\
\hline $\mathbf{Y}$ & 22,24 & 19,1 & 18,43 & 24,93 & 24,21 & 29,46 & 54,31 & 16,44 & 26,49 & 7,09 & 9,88 & 24,73 \\
\hline Th & 0,3 & 0,2 & 0,1 & 2,4 & 0,4 & 0,2 & 0,4 & 0,4 & 2,8 & $<0,1$ & $<0,1$ & 0,9 \\
\hline $\mathbf{U}$ & 0,07 & 0,1 & 0,09 & 0,5 & 0,13 & 0,14 & 0,09 & 0,09 & 0,6 & $<0,05$ & 0,05 & 0,2 \\
\hline$[\mathbf{L a} / \mathbf{Y b}] \mathbf{n}$ & 1,24 & 1,55 & 1,69 & 7,56 & 1,48 & 2,95 & 1,58 & 1,24 & 7,35 & 1,6 & 1,42 & 1,44 \\
\hline Média & 1,24 & \multicolumn{2}{|c|}{1,62} & \multicolumn{2}{|c|}{4,52} & \multicolumn{2}{|c|}{2,27} & \multicolumn{3}{|c|}{3,39} & \multicolumn{2}{|c|}{1,43} \\
\hline $\mathbf{E u}^{*}$ & 12,01 & \begin{tabular}{l|l|}
11,49 \\
\end{tabular} & 12,94 & 33,4 & 12,77 & 21,92 & 47,45 & 8,34 & 34,13 & 3,24 & 5,19 & 13,31 \\
\hline Média & 12,01 & & 01 & & & & & & 15,24 & & & \\
\hline $\mathbf{E u} / \mathbf{E u}{ }^{*}$ & 0,96 & 1,03 & 0,98 & 0,75 & 1,1 & 1,05 & 0,93 & 0,98 & 0,79 & 1,05 & 1,02 & 0,86 \\
\hline Média & 0,96 & & 00 & & & & & & 0,94 & & & \\
\hline Ce-Sm & 0,65 & 1,06 & 0,84 & 1,58 & 1,03 & 0,68 & 0,18 & 0,92 & 1,63 & 0,88 & 0,94 & 1,09 \\
\hline Média & 0,65 & & 95 & & & & & & 1,14 & & & \\
\hline Gd-Yb & 1,4 & \begin{tabular}{l|l}
1,27 \\
\end{tabular} & 1,46 & 3,12 & 1,15 & 1,5 & 1,78 & 0,87 & 2,86 & 0,89 & 1,1 & 0,96 \\
\hline Média & 1,4 & & 37 & & & & & & 1,54 & & & \\
\hline
\end{tabular}



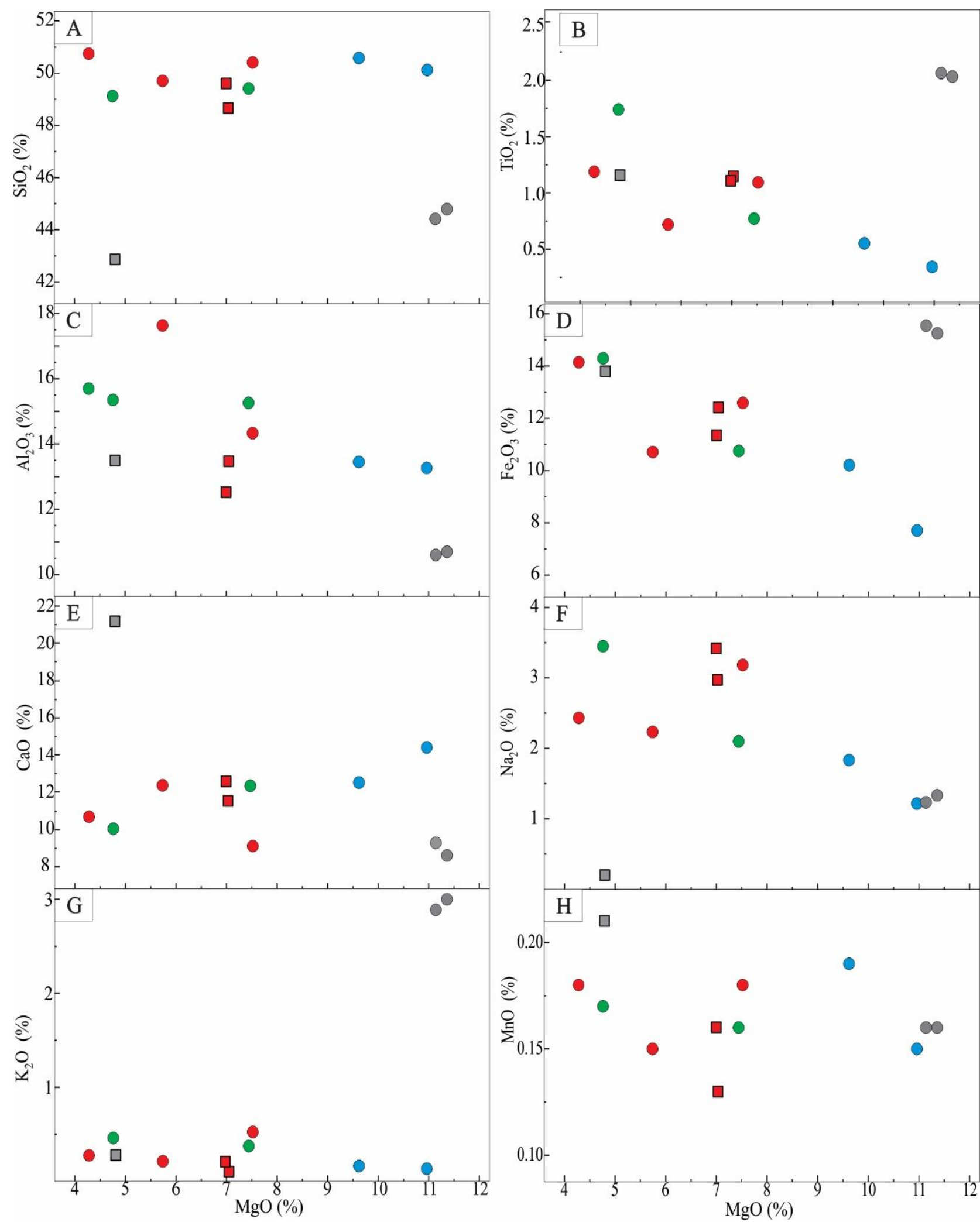

Figura 7 - Diagramas geoquímicos de variação para elementos maiores tipo Harker (1909) das amostras de rochas básicas/ultrabásicas.

Observa-se valores mais elevados para as rochas ricas em magnésio, com exceção do ultrabásica que apresentam natureza alcalinas rica em potássio, em relação as demais amostras.

Portanto, sugere-se um processo de fracionamento magmático envolvendo principalmente os plagioclásios e minerais ferromagnesianos, a partir da segregação de minerais ferromagnesianos e, enriquecimento em plagioclásio, com consequente enriquecimento de $\mathrm{Sr}, \mathrm{Zr}$ e Y e empobrecimento em Ba no líquido magmático. $\mathrm{O}$ decréscimo do $\mathrm{Zr}$ indica fracionamento ao longo da evolução dos líquidos e seu aumento nos líquidos mais diferenciados 
finais, sugere o fracionamento simultâneo de titanomagnetita e zircão no processo evolutivo.

No diagrama composicional da figura 9A (Middlemost, 1994), as amostras distribuem-se dominantemente entre o gabro/basaltos, com exceção de três amostras de natureza ultrabásica

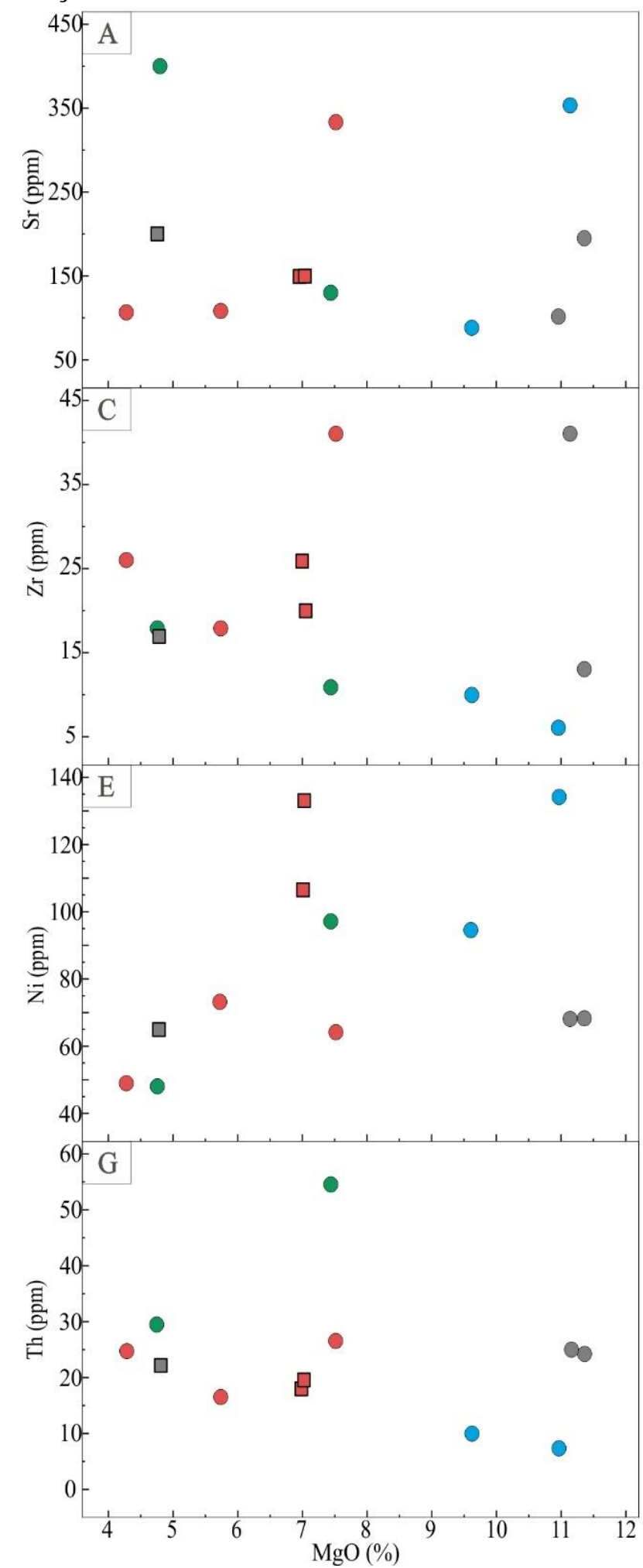

com teores de $\mathrm{SiO}_{2}<45 \%$, sendo uma que se encontra inserida na unidade do Grupo Itaiacoca, a de mais baixa sílica $( \pm 42 \%)$, baixo potássio (< $2 \%)$ e baixo magnésio $( \pm 5 \%)$ e que se assemelha no diagrama composicional à picrito (olivina basalto).

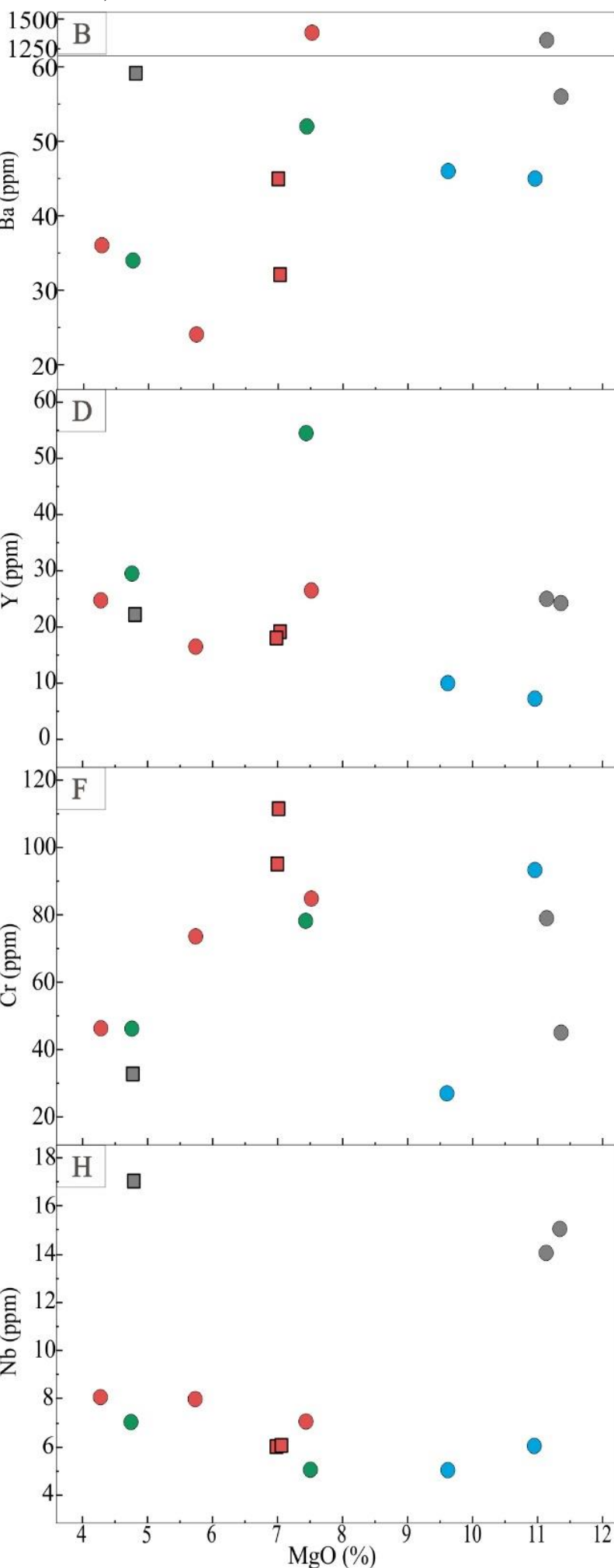

Figura 8 - Diagramas geoquímicos binários para elementos traço para as rochas de composição básicas/ultrabásicas.

As amostras de rochas ultrabásicas inseridas na Formação Água Clara, com valores próximos de $\pm 45 \%$ de $\mathrm{SiO}_{2}$, elevado magnésio e potássio e com tendências fortemente alcalinas, sobrepõem o campo do basanito.

No diagrama de classificação de série magma- 
tica da figura 9B (Middlemost, 1975), as amostras de basaltos são na maioria coincidentes ao campo dos basaltos subalcalinos de natureza toleítica de baixo a médio potássio.

As rochas ultrabásicas distribuem-se, na de menor sílica, no campo dos basaltos subalcalinos de médio potássio; e as duas com valores mais elevados de sílica, no campo dos basaltos alcalinos. A afinidade toleítica dessas rochas é evidenciada no diagrama AFM de Irvine \& Baragar (1971) (Figura 9C).

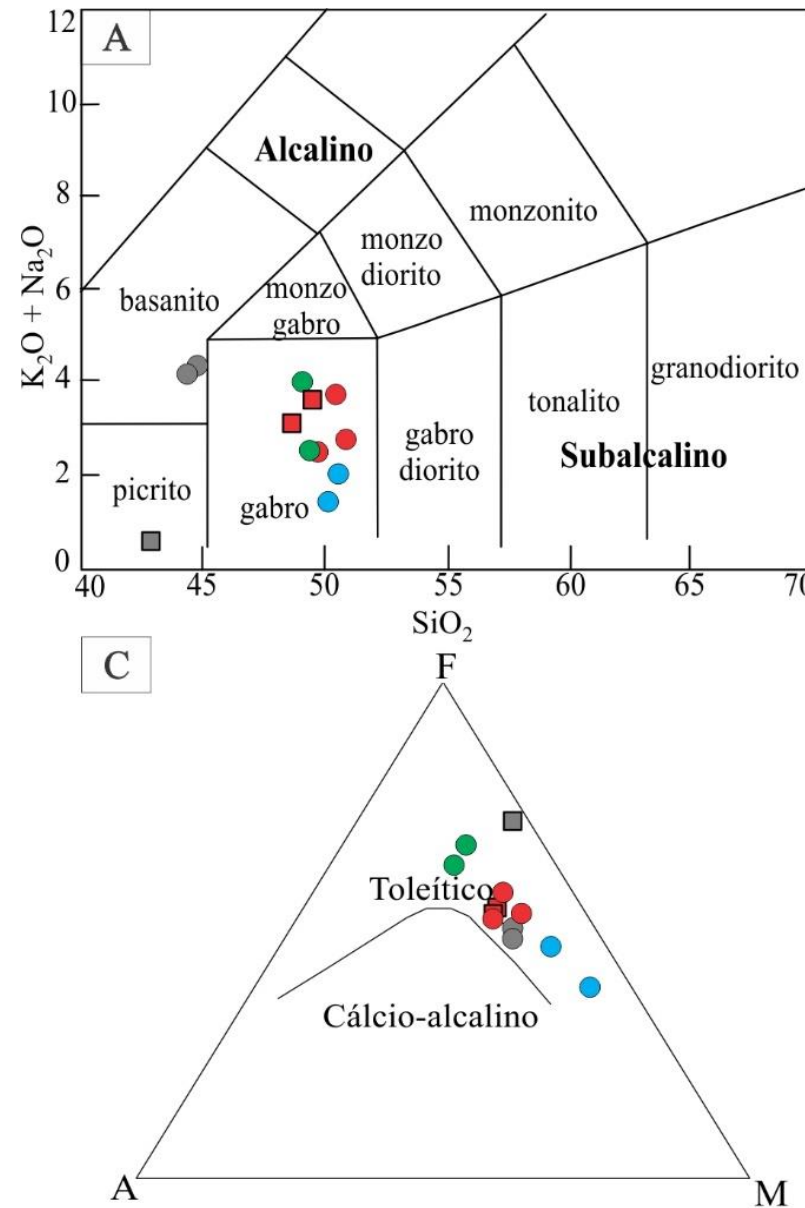

No diagrama de classificação da figura 9D (Jensen, 1976), a maioria das amostras de composição básicas-ultrabásicas, da Formação Água Clara e a ultrabásica do Grupo Itaiacoca corresponde a basaltos subalcalinos de natureza Fe-toleítico, com exceção de uma amostra classificada como Mg-toleíto.

As amostras de rochas ultrabásicas inseridas nas rochas da unidade metassedimentar do Grupo Itaiacoca, apresentam-se na transição entre os basaltos Fe-toleíticos a basaltos komatíticos.
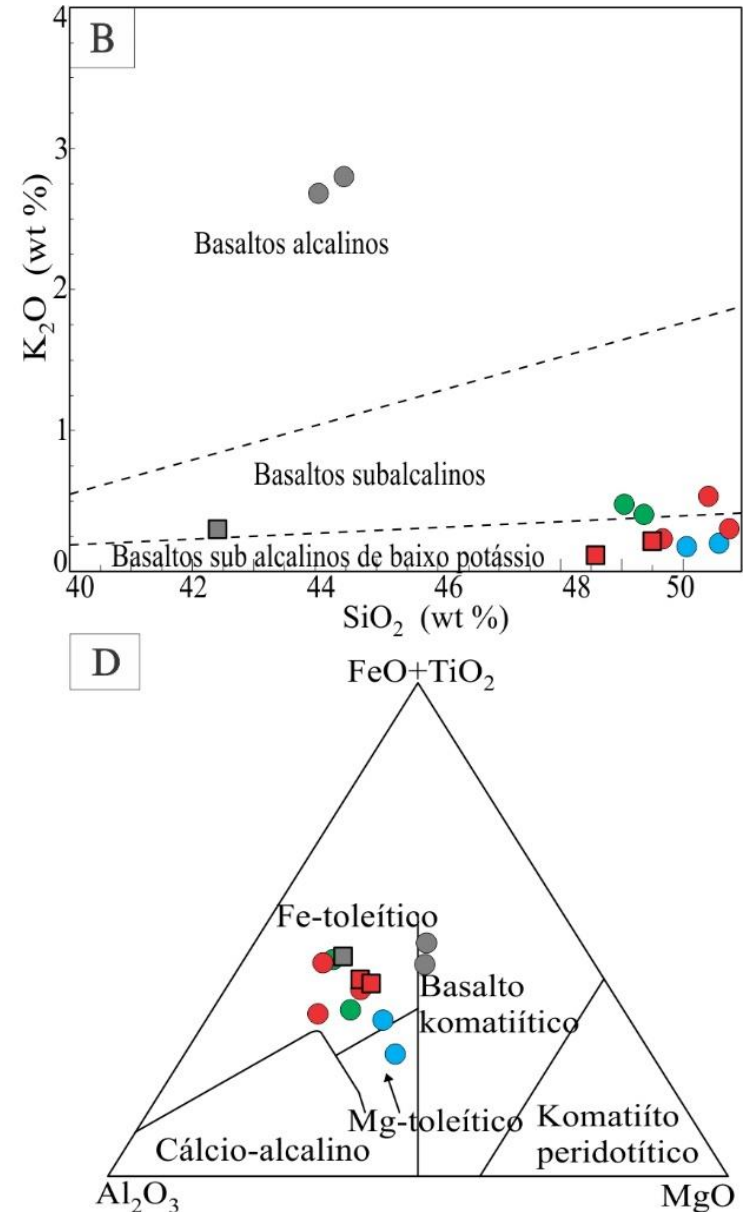

Figura 9 - Diagramas geoquímicos de classificação de amostras e de ambiente tectônico para as rochas de composição básicas/ultrabásicas. Legenda: A) Middlemost (1994), B) Middlemost et al. (1975), C) Irvine \& Baragar (1971), D) Jensen (1976).

Nos diagramas de classificações tornou-se possível distinção de dois grandes agrupamentos: um de rochas ultrabásicas, definido como (U1) Itaiacoca e (U2) Água Clara e o agrupamento das rochas básicas subdivididas em dois grandes grupos, as básicas do Grupo Itaiacoca (B1) e as básicas da Formação Água Clara, divididas em três grupos, designados de B2, B3, B4 (Tabela 4).

Observa-se na figura 10A (Mullen, 1983), que as amostras correlacionadas ao Grupo Itaiacoca, de composição ultrabásica komatiítica (U1) distribuem-se no campo dos basaltos de cadeia mesoceânicas (MORB), mesmo padrão assumido para os basaltos toleíticos (B1).

Para as amostras da Formação Água Clara, pode ser observado na figura $10 \mathrm{~A}$ que as rochas ultrabásicas (U2) correspondem a basaltos alcalinos de ilha oceânica (OIA) (pluma). As rochas básicas (B4) correspondem a basalto toleítico de arco de ilha oceânica (IAT) que transicionam para boninito, rocha rica em magnésio e sílica, especifica de arcos de ilha oceânicos da fase inicial da subducção. As amostras do grupo B2 e B3 são amostras que se encontram na transição de ambiente de arco de ilha oceânico e MORB. 

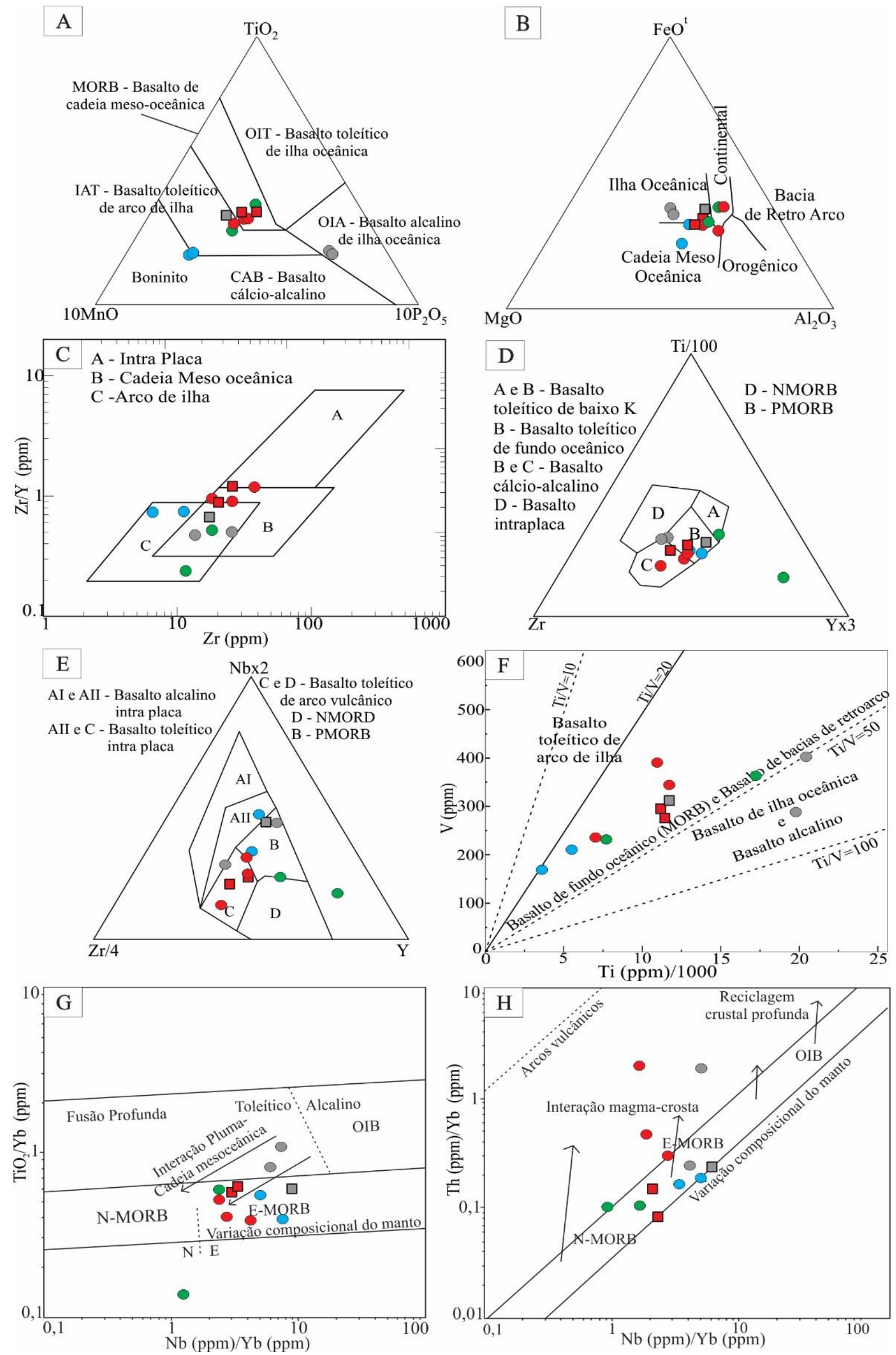

Figura 10 - Diagramas geoquímicos de classificação de amostras e de ambiente tectônico para as rochas de composição básicas/ultrabásicas. Legenda: A) Mullen (1983); B) Pearce et al. (1977), C) Pearce \& Norry (1979), D) Pearce \& Can (1973), E) Meschede (1986); F) Shervais (1982); G e H) Pearce (2008). 
Na figura 11B de Pearce et al. (1977) as amostras distribuem-se, perante aos campos disponíveis, basicamente no campo de basalto de cadeia mesoceânica (MORB). As amostras ultrabásicas (U2) concentram-se nos basaltos alcalinos de ilha oceânica (OIA) (pluma)

No diagrama da figura 10C (Pearce \& Norry, 1979) as rochas apresentam característica de basaltos toleíticos de cadeia mesoceânicas (MORB) e com amostras básicas (B2 e B3) distribuídas em basaltos toleíticos de arco de ilha oceânica, similar a figura 10A.

Pelo diagrama de Pearce \& Can (1973) (Figura 10D) as amostras dispõem-se dominantemente no campo dos basaltos toleíticos de fundo oceânico, especificamente do tipo P-MORB ou E-MORB.

Meschede (1986) (Figura 10E) reforça as características de basaltos toleíticos de baixo $\mathrm{K}$ de cadeia mesoceânicas enriquecida (E-MORB), com amostras transicionando para os basaltos alcalinos de ilha oceânica. Amostras do grupo $\mathrm{B} 1$, nas figuras $10 \mathrm{D}$ e $10 \mathrm{E}$, ocorrem fora dos campos composicionais devido aos valores elevados de Y.

No diagrama da figura 10E de Shervais (1982) a razão de $\mathrm{Ti} / \mathrm{V}$ são diagnósticas de ambientes tectônicos distintos e a razão $\mathrm{Ti} / \mathrm{V}$ de magmas primários derivados do manto aumenta com o decréscimo da fração de fundido produzida.

As razões Ti/V entre 20 - 50 possibilitam a geração a partir da fusão parcial sob condições relativamente redutoras de basaltos de fundo mesoceânicas (MORB), com possibilidades da sua formação num ambiente do tipo "back-arc".

Destacam-se as amostras (B4) da Formação Água Clara de basaltos toleíticos de arco de ilha. Os basaltos alcalinos de ilha oceânica (U1) da Formação Itaiacoca apresentam razão de Ti/V menores que 50 nos diagramas de Pearce (2008) (Figura 10F). A variabilidade da razão de Ti/Yb é sensível à profundidade da fusão parcial que deu origem aos magmas de basaltos alcalinos de ilha oceânica (pluma).

No diagrama da figura 10G observa-se que as rochas se posicionam principalmente no campo de composição de fonte mantélica de basaltos de cadeia mesoceânicas do tipo E-MORB (enriquecido) e, pela razão obtida, a geração por fusão parcial rasa fica evidente. As amostras de rochas ultrabásicas (U1 e U2) posicionam-se acima do campo de variação das fontes mantélicas do tipo E-MORB, sugerindo fusão mais profunda relacionada à interação com pluma e definindo os basaltos de ilha oceânica.

No diagrama de Pearce (2008) a variação da razão $\mathrm{Th} / \mathrm{Yb}$ é sensível à composição da fonte do magmatismo básico e aos efeitos de contaminação crustal ou relacionados ao componente de subducção.

$\mathrm{Na}$ figura $10 \mathrm{H}$, observa-se uma distribuição do maior número de amostras de um enriquecimento progressivo da fonte mantélica E- MORB (enriquecida), com algumas amostras apresentando variações para o campo de interação de magma e crosta, resultado do processo de subducção.

No diagrama multielementar de elementostraço normalizado segundo Weaver \& Tarney (1984) com os valores para a crosta inferior (Figura 11A), os dados geoquímicos evidenciam claramente dois grupos com comportamento geoquímico distintos e, portanto, a existência de dois grupos de protólitos ígneos: as rochas ultrabásicas (Figura 11C) e básicas (Figura 11E).

Observa-se que os litotipos exibem um empobrecimento em $\mathrm{Ba}, \mathrm{Ke} \mathrm{Zr}$ e enriquecimento em $\mathrm{Nb}, \mathrm{Sr}$ e $\mathrm{Ti}$, evidenciando processos de fracionamento envolvendo plagioclásio e minerais máficos. Estes apresentam-se com anomalias positivas em função da segregação e enriquecimento de plagioclásio para as fases mais diferenciadas.

O padrão de fracionamento resultante da composição de elementos terras raras (ETR) normalizados pelo Condrito de Boynton (1984) (Figura 11B), evidencia uma distribuição de ETR distinta em um agrupamento de rochas ultrabásicas dividindo o comportamento geoquímico em dois grupos (U1 e U2) bem definidos (Figura 11D) e o agrupamento das rochas básicas subdivididas em três grupos designados de B1 e B3, B2 e B4 (Figura 11F)

$\mathrm{Na}$ figura 11D, das rochas ultrabásicas, reconhece-se dois padrões geoquímicos de ETR, sendo que (U1) do Grupo Itaiacoca apresenta padrão simétrico sub-horizontal, (razão média $\mathrm{La} / \mathrm{Yb}>1,24), \mathrm{Eu}^{*}=12,01, \mathrm{Eu} / \mathrm{Eu}^{*}=0,96 \mathrm{e}$, mostra uma distribuição com fraco enriquecimento em ETR leves (ETRL) (razão $\mathrm{Ce}-\mathrm{Sm}=0,65)$ em relação aos ETR pesados (ETRP) (razão Gd-Yb=1,40). Padrão típico das rochas ultrabásicas komatiíticas (U1) associadas à cadeia mesoceânica (MORB). 
As amostras de rochas ultrabásicas (U2), da Formação Água Clara, apresentam padrão fortemente assimétrico (razão média $\mathrm{La} / \mathrm{Yb}>$ $4,52), \mathrm{Eu}^{*}=23,08, \mathrm{Eu} / \mathrm{Eu}^{*}=0,93$ e mostram uma distribuição com forte enriquecimento em ETR leves (ETRL) (razão $\mathrm{Ce}-\mathrm{Sm}=1,30$ ) em relação aos ETR pesados (ETRP) (razão Gd-Yb=2,14). Padrão típico das rochas ultrabásicas alcalinas de ilha oceânica (OIA) (pluma).

As amostras de rochas básicas definem três padrões distintos. As amostras de rochas (B2) da Formação Água Clara apresentam padrão fortemente assimétrico (razão média $\mathrm{La} / \mathrm{Yb}>$ 2,27), $\mathrm{Eu}^{*}=34,69, \mathrm{Eu} / \mathrm{Eu}^{*}=0,99$ e mostram uma distribuição com forte enriquecimento em ETR leves (ETRL) (razão $\mathrm{Ce}-\mathrm{Sm}=0,43$ ) em relação aos ETR pesados (ETRP) (razão Gd-Yb=1,64). Padrão de rochas básicas toleíticas associadas a cadeia mesoceânicas (MORB), com possível

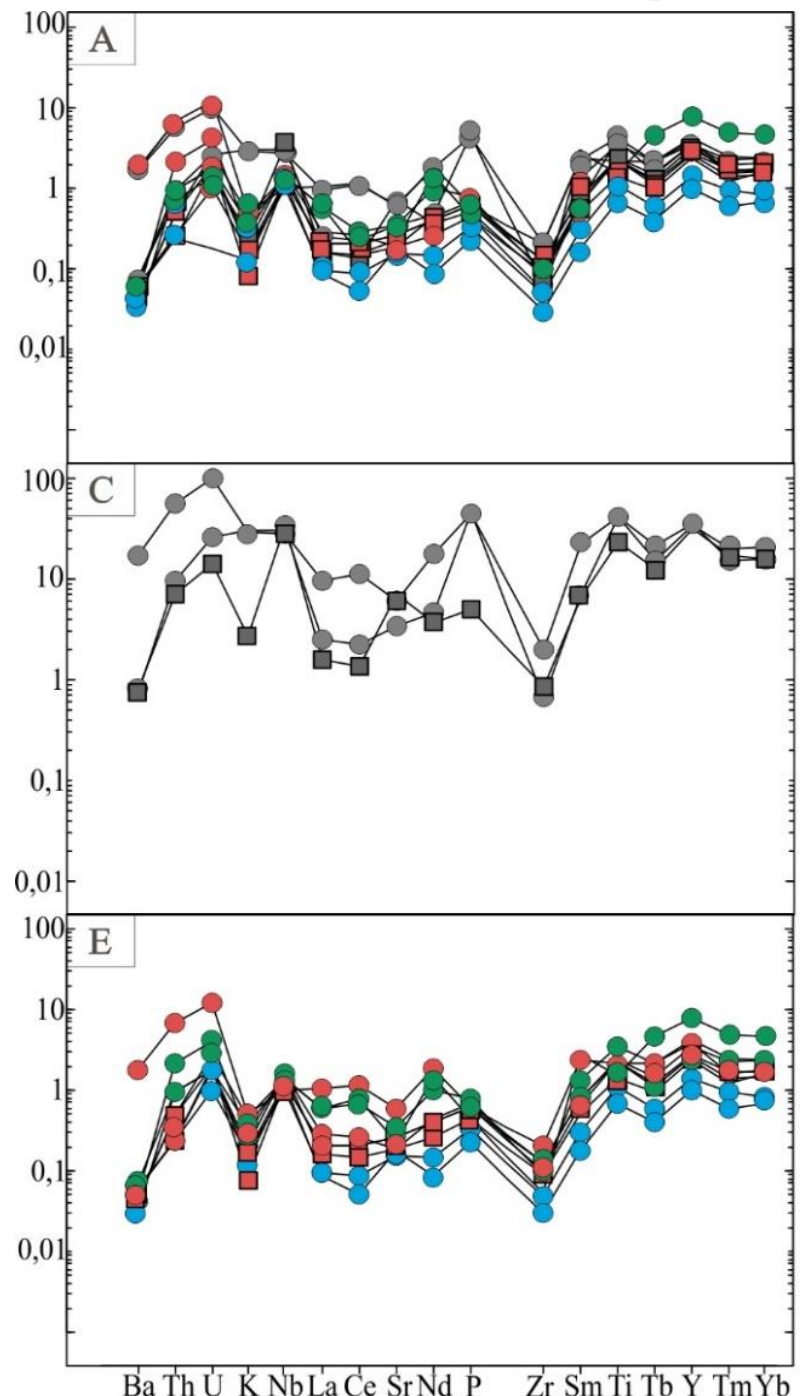

interação da crosta na fase de subducção.

As amostras de rochas básicas (B1 e B3) da Formação Água Clara apresentam padrão fortemente assimétrico (razão média $\mathrm{La} / \mathrm{Yb}>$ $3,39), \mathrm{Eu}^{*}=15,24, \mathrm{Eu} / \mathrm{Eu}^{*}=0,94$ e mostram uma distribuição com forte enriquecimento em ETR leves (ETRL) (razão $\mathrm{Ce}-\mathrm{Sm}=1,14)$ em relação aos ETR pesados (ETRP) (razão Gd-Yb=1,54). Padrão típico de rochas básicas toleíticas associadas a rifts de cadeia mesoceânica tipo (MORB)

As amostras de basaltos (B4) apresentam padrão simétrico (razão média $\mathrm{La} / \mathrm{Yb}>1,43$ ), $\mathrm{Eu}^{*}=9,25, \mathrm{Eu} / \mathrm{Eu}^{*}=0,94$ e mostram uma distribuição com forte enriquecimento em ETR leves (ETRL) (razão $\mathrm{Ce}-\mathrm{Sm}=1,02)$ em relação aos ETR pesados (ETRP) (razão Gd-Yb=1,03). Padrão típico de basaltos toleíticos de arco de ilha.

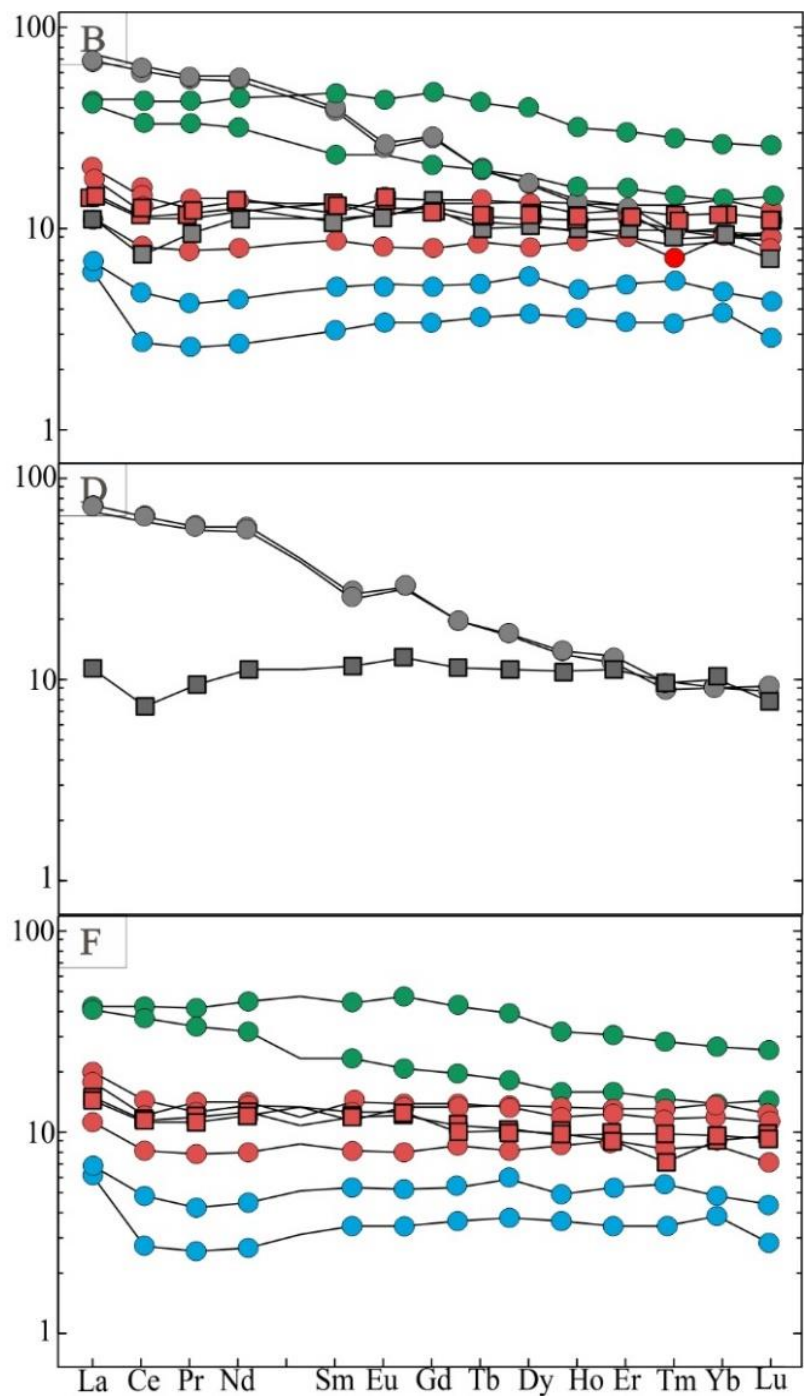

Figura 11 - Diagramas de elementos incompatíveis (Spider) para as rochas de composição básica normalizado segundo os seguintes valores. A) Weaver \& Tarney (1984) para a crosta inferior. B) Boynton (1984) para meteoritos condríticos; C) Weaver \& Tarney (1984), com destaque para rochas ultrabásicas (U1 e U2); D) Boynton (1984), com destaque para rochas ultrabásicas (U1 e U2); E) Weaver \& Tarney (1984), com destaque para rochas básicas (B1, B2, B3 e B4); F) Boynton (1984), com destaque para rochas básicas (B1, B2, B3 e B4). 


\section{CONCLUSÕES}

As rochas ortoderivadas de composição básica e ultrabásica são representadas por anfibolito, metabasíto e metaultrabásitos de idade meso- a neoproterozoica.

Encontram-se inseridas em rochas da sequência metavulcanossedimentar do Supergrupo Açungui, especificamente na Formação Água Clara e no Grupo Itaiacoca.

As rochas básicas são agrupadas em anfibolito e hornblenda xisto, e constituídas por três agrupamentos minerais principais: 1 - raros pseudomorfos de labradorita e augita intensamente alterados, que representam uma associação reliquiar; 2 - paragênese mineral principal de ferrotschermakita- ferrohornblendamagnesio-hornblenda \pm oligoclásio/andesina, representando o ápice do metamorfismo regional progressivo $\mathrm{M}_{1}$, de $611^{\circ} \mathrm{C}$ a $621^{\circ} \mathrm{C}$ de temperatura e 6,5 kbar a 7,3 kbar $( \pm 0,6)$ (Fácies anfibolito médio); 3 - paragênese mineral de actinolita/tremolita \pm albita, do retrometamorfismo regional $\mathrm{M}_{3}$, característica de fácies xisto verde baixo a médio. Como minerais acessórios ocorrem quartzo, titanita, zircão, apatita e minerais opacos. Minerais secundários são carbonato, talco, sericita, epidoto, clinozoisita, leucoxênio, hidróxidos e demais minerais opacos. Secundariamente, ocorrem termos metaultrabásicos, caracterizados como talco-epidoto-tremolita xisto a tremolitito, constituído por actinolita/tremolita, epidoto, talco, raro plagioclásio e quartzo.

Os protólitos ígneos máficos podem ser divididos em dois grupos principais: um de rochas ultrabásicas, definido como Itaiacoca (U1) e Água Clara (U2); e o agrupamento das rochas básicas, subdivididas em dois grandes grupos, as básicas do Grupo Itaiacoca (B1) e as básicas da Formação Água Clara, divididas em três grupos, designados de B2, B3, B4.

Dados geoquímicos composicionais classificam as rochas como gabro (B1 a B4), picrito (U1) e basanito (U2), sub alcalinos de baixo potássio (U1 e B1 a B4) a alcalinos (U2), Fe-toleíticos (U1 e B1 a B3) a Mg-toleíticos (B4), com leve tendência à basaltos komatiíticos (U2).

Já os dados geotectônicos, corroborados pelo comportamento dos elementos traços e dos ETRs, indicam três assinaturas principais para os grupos anfibolíticos: rochas básicas toleíticas (B1 e B3) a komatiíticas (U1) estão associadas a cadeia mesoceânicas (MORB), com possível interação da crosta na fase de subducção (B2); rochas ultrabásicas alcalinas de ilha oceânica (OIA) (U2); e basaltos toleíticos de arco de ilha (B4).

Portanto, os eventos magmáticos estão correlacionados ao estágio inicial de abertura de bacia ou ao início de fechamento à fase inicial de natureza toleítica de fundo oceânico, associado a basaltos alcalinos de ilha oceânica.

O comportamento dos elementos traços sugere que diferentes fontes estiveram envolvidas na geração dos metabasitos a partir da interação entre fonte mantélica do tipo E-MORB enriquecida ou interação com rochas da crosta no processo de subducção.

\section{AGRADECIMENTOS}

Os autores agradecem o apoio do CNPq (proc. $n^{\text {o: }}$ 304614/2017-3).

\section{REFERÊNCIAS}

ALGARTE, J.P.; MARTINS, A.J.M.; MORGENTAL, A.; DAITX, E.C.; ANDRADE Jr, F.S.; BATOLLA Jr, F.; FERREIRA, F.J.F.; PINTO, G.G.; CUNHA, H.C.S.; DRUMOND, J.B.V., RODRIGUES, J.C.; YAMAMOTO, K.; KAEFER, L.Q.; CHIEREGATI, L.A.; PINHO FILHO, W.D.; ADDAS, W. Projeto Sudeste do Estado de São Paulo. Relatório Final. São Paulo: DNPM/CPRM, 1973

ALMEIDA, F.F.M. Origem e evolução da Plataforma Brasileira. Rio de Janeiro. Boletim DNPM/DGM, v. 241, 38 p., 1967.

ALMEIDA, F.F.M.; HASUI, Y.; BRITO-NEVES, B.B.; FUCK, R.A. Províncias estruturais brasileiras. SIMPÓSIO GEOLOGIA NORDESTE, 8, 1977, Campina Grande. Anais... Campina Grande: Sociedade Brasileira de Geologia, p. $363-$ 391, 1977.

ALMEIDA, F.F.M.; HASUI, Y.; PONÇANO, W.L.; DANTAS, A.S.L.; CARNEIRO, C.D.R.; MELO, M.S.; BISTRICH, C.A. Mapa Geológico do estado de São Paulo em escala 1:
500.000. Nota explicativa. São Paulo, IPT, Monografias 6, v. 1, 126p., 1981a.

ALMEIDA, F.F.M.; HASUI, Y.; BRITO-NEVES, B.B.B.; FUCK, R.A. Brazilian structural provinces: an introduction. Earth Sciences Reviews, v. 17, p. 1-29, 1981b.

ALMEIDA, M.A.; BISTRICHI, C.A.; STEIN, D.P. A Formação Água Clara na região de Araçaíba, Estado de São Paulo: litotipos, metamorfismo e deformação. In: CONGRESSO BRASILEIRO DE GEOLOGIA, 35. 1986. Goiânia. Anais... Goiânia: Sociedade Brasileira de Geologia,1986, v. 2, p. 905918.

ALMEIDA, M.A. Geologia da formação Água Clara na região de Araçaíba - SP. São Paulo, 1989. 184 p. Dissertação (Mestrado), Instituto de Geociências, Universidade de São Paulo, São Paulo.

BISTRICHI, C.A.; CARNEIRO, C.D.R.; DANTAS, A.S.L.; PONÇANO, W.L.; CAMPANHA, G.A.C.; NAGATA, N.; 
ALMEIDA, M.A.; STEIN, D.P.; MELO, M.S.; CREMINI, O.A. Mapa geológico do Estado de São Paulo em 1: 500.000 IPT/Pró-Minério, São Paulo, v. 2, 1981.

BISTRICHI, C.A.; ALMEIDA, M.A.; STEIN, D.P. Geologia das folhas Barra do Chapéu (SG.22-X-B-I-4) e Araçaíba (SG.22-XF-II-3), estados de São Paulo e Paraná. São Paulo, Contrato IPT/ Pró-Minério, v. 1, 104 p. (IPT. Relatório 22.150), 1985.

BOLONINI, T.M. \& GODOY, A.M. Geologia e Geoquímica das rochas graníticas do Maciço Capão Bonito, SP. São Paulo, Geociências, v. 32, n. 3, p. 452-470, 2013.

BOYNTON, W.V. Geochemistry of the rare earth elements: meteorite studies. In: HENDERSEN, P. (ed.). Rare earth element geochemistry. Elsevier Amsterdam, p. 63-114, 1984.

BRITO NEVES, B.B. América do Sul: quatro fusões, quatro fissões e o processo acrescionário andino. Revista Brasileira de Geociências, v. 29, n. 3, p. 379-392, 1999.

CAMPANHA, G.A.C. Tectônica Proterozoica no Alto e Médio Vale do Ribeira, Estados de São Paulo e Paraná. São Paulo, 1991. 296 p. Tese (Doutorado), Instituto de Geociências Universidade de São Paulo

CAMPANHA, G.A.C. O papel do sistema de zonas de cisalhamento transcorrentes na configuração da porção meridional da Faixa Ribeira. São Paulo, 2002. 105 p. Tese (Livre-Docência), Instituto de Geociências-Universidade de São Paulo.

CAMPANHA, G.A.C. \& SADOWSKI, G.R. Tectonics of the southern portion of the Ribeira Belt (Apiaí Domain). Precambrian Research, v. 98, p. 31-51, 1999.

CAMPANHA, G.A.C.; BISTRICHI, C.A.; ALMEIDA, M.A. Considerações sobre a organização litoestratigráfica e evolução tectônica da faixa de dobramentos Apiaí. In: SIMPÓSIO SULBRASILEIRO DE GEOLOGIA, 3, 1987, Curitiba. Atas...Curitiba: SBG, v. 2, p. 725-742, 1987.

CAMPANHA, G.A.C.; FALEIROS, F.M.; BASEI, M.A.S.; TASSINARI, C.C.G.; NUTMAN, A.P.; VASCONCELOS, P.M. Geochemistry and age of mafic rocks from the Votuverava Group, southern Ribeira Belt, Brazil: Evidence for $1490 \mathrm{Ma}$ oceanic back-arc magmatism. Pre-cambrian Research, v. 266, p. 530-550, 2015.

CHIODI FILHO, C.; TAKAHASHI, A.T.; SILVA, C.R.; FERREIRA, J.C.G. Projeto Capão Bonito. Relatório Final CPRM, v. I, Rio de Janeiro, 121 p., 1983.

CORDANI, U.G.; BITTENCOURT, I.; BETTENCOURT, J.S.; GOMES, C.B.; LELIS, H.S.; MELFI, A.J. Geologia da Folha de Guapiara, SP e PR. In: CONGRESSO BRASILEIRO DE GEOLOGIA, 25, 1971, São Paulo. Boletim de Resumos...São Paulo: Sociedade Brasileira de Geologia, 1971, p. 93.

CORDANI, U.G.; DELHAL, J.; LEDENT, O. Orogenèses superposeés dans le Précambrien du Brésil sud-oriental (États du Rio de Janeiro et de Minas Gerais). Revista Brasileira de Geociências, v. 3, n. 1, p. 1-22, 1973.

CORDANI, U.G.; SATO, K.; TEIXEIRA, W.; TASSINARI, C.C.G.; BASEI, M.A.S. Crustal evolution of the South American platform. In: CORDANI, U.G.; MILANI, E.J.; THOMAZ FILHO, A.; CAMPOS, D.A. (Eds.) Tectonic evolution of South America, Rio de Janeiro: p. 19- 40, 2000.

DANTAS, E.L.; HACKSPACHER, P.C.; FETTER, A.H.; SATO, K., PIMENTEL, M.M.; GODOY, A.M. ND Isotope Systematics Related to Proterozoic Evolution of the Central Ribeira Belt in the State of São Paulo, SE Brazil. Revista Brasileira de Geociências, v. 30, n. 1, p. 140-143, 2000.

FALEIROS, F.M. Evolução de Terrenos TectonoMetamórficos da Serrania do Ribeira e Planalto do Alto Turvo (SP, PR). São Paulo, 2008. 306 p. Tese (Doutorado), Instituto de Geociências - Universidade de São Paulo.

FALEIROS, F.M.; CAMPANHA, G.A.C.; BELLO, R.M.S.; FUZIKAWA, K. Quartz recrystallization regimes, c-axis texture transitions and fluid inclusion re-equilibration in a prograde greenschist to amphibolite facies mylonite zone (Ribeira Shear Zone, SE Brazil). Tectonophysics, v. 485, p.
193-214, 2010.

FALEIROS, F.M.; FERRARI, V.C.; COSTA, V.S.; CAMPANHA, G.A.C. Geoquímica e petrogênese de metabasítos do grupo Votuverava (Terreno Apiaí, Cinturão Ribeira Meridional): evidências de uma bacia retro arco caliminiana. Geologia USP, Série Científica, v. 11, n. 2, p. 135-155, 2011.

FALEIROS, F.M.; MORAIS, S.M.; COSTA, V.S. Geologia e Recursos Minerais da Folha Apiaí - SG.22-X-B-V - Estados de São Paulo e Paraná, escala 1:100.000. 1. ed. São Paulo: Programa Geologia do Brasil, CPRM-Serviço Geológico do Brasil, 107 p., 2012.

FASSBINDER, E. A unidade Água Clara no contexto do Grupo Açungui: um modelo transpressivo de colisão oblíqua no Neoproterozoico paranaense. São Paulo, 1996. 207 p. Tese (Doutorado), Instituto de Geociências Universidade de São Paulo.

FIORI, A.P. Tectônica e estratigrafia do Grupo Açungui a norte de Curitiba. São Paulo, 1990. 261 p. Tese (Livre Docência). Instituto de Geociências, Universidade de São Paulo, 1990.

FIORI, A.P. Tectônica e estratigrafia do Grupo Açungui, PR. Boletim IG-USP. Série Científica, v. 23, p. 55-74, 1992.

FIORI, A.P. Evolução geológica da bacia Açungui. Boletim Paranaense de Geociências, v. 42, p. 7-27, 1994.

FRANCISCONI, O. Mapa Geológico, Folha Itararé (SG.22-X-BI) escala 1:100.000. In: SILVA, A.T.S.F.; FRANCISCONI, O.; GODOY, A.M; BATOLLA JR, F. Projeto Integração e Detalhe Geológico no Vale do Ribeira. Relatório Final. São Paulo, DNPN/CPRM, 1981b, v. 1/2.

FRASCÁ, M.H.B.O.; CAMPANHA, G.A.C.; FIGUEIREDO, M.C.H.; SADOWSKI, G.R. Geoquímica de metabasíto do alto e médio vale do Ribeira, São Paulo e Paraná. Boletim IG-USP, Publicação Especial, n. 18, p. 129-131, 1996.

FRASCÁ, M.H.B.O.; CAMPANHA, G.A.C.; FIGUEIREDO, M.C.H.; SADOWSKI, G.R. Geoquímica e ambiência tectônica de metabasitos do alto e médio Vale do Ribeira, São Paulo e Paraná. Revista Brasileira de Geociências, v. 27, n. 1, p. 4148, 1997.

FRASCÁ, M.H.B.O.; FIGUEIREDO, M.C.H.; ALMEIDA, M.A.; COUTINHO, J.M.V. Petrografia e geoquímica da Formação Água Clara, região de Araçaíba, SP. Geologia USP, Série Científica, v. 21, p. 73-92, 1990.

FRITZONS JÚNIOR, O.; PIEKARZ, G.F.; FALCADE, D. Geologia e potencial econômico do Grupo Setuva (PR). In: CONGRESSO BRASILEIRO DE GEOLOGIA, 32, Salvador. Anais...Salvador: Sociedade Brasileira de Geologia, 1982. v. 3, p. 991-1001

FUCK, R.A.; BRITO NEVES, B.B. B.; SCHOBBENHAUS, C. Rodínia descendants in South America. Pre-cambrian Research, v. 160, n. 1-2, p. 108-126, 2008.

GODOY, A.M.; VIEIRA, O.A.R.P.; LEITE JUNIOR, W.B.; HACKSPACHER, P.C.; MATA, S.P., ZENERO, J.M. Geologia e Tectônica da região da Folha Topográfica de Capão Bonito na escala 1:50.000, sudeste do estado de São Paulo. Geociências, v. 38, n. 1, p. 51-71, 2019.

HACKSPACHER, P.C. \& GODOY, A.M. Vertical Displacement During Post-Colisional Escape Tectonic (Brasiliano Orogeny) of The Ribeira Belt, São Paulo, Brazil. Journal of African Earth Sciences. Elsevier Science Ltd., Africa do Sul, v. 29, n. 1, p. 25-32, 1999.

HACKSPACHER, P.C.; DANTAS, E.L.; SPOLADORE, A.; FETTER, A.H., OLIVEIRA, M.A.F. Evidence of Neoproterozoic back arc basin development in the Central Ribeira Belt, Southeastern Brazil new geochronological and geochemical constraints from São Roque Açungui groups. Revista Brasileira de Geociências, v. 30, n. 1, p. 110-114, 2000.

HARKER, A. The Natural History of Igneous Rocks. London, Methuen, 384, p. 1909.

HASUI, Y. A grande Colisão Pré-Cambriana do Sudeste 
brasileiro e a Estruturação Regional. São Paulo, UNESP, Geociências, v. 29, n. 2, p. 141-169, 2010.

HASUI, Y. Sistema Orogênico Mantiqueira. In: HASUI, Y., CARNEIRO, C.D.R., ALMEIDA, F.F.M.A., BARTORELLI, A. (org.) Geologia do Brasil. São Paulo, Beca, p. 331-372, 2012.

HASUI, Y. \& OLIVEIRA, M.A.F. Província Mantiqueira. Setor Central. In: ALMEIDA, F.F. \& HASUI, Y. (Eds). O Précambriano do Brasil. São Paulo, p. 308-344, 1984.

HASUI, Y.; CARNEIRO, C.D.R.; BISTRICHI, C.A. Os Granitos e Granitóides da Região de Dobramentos Sudeste nos Estados de São Paulo e Paraná. In: CONGRESSO BRASILEIRO DE GEOLOGIA, 30, 1978, Recife. Anais...Recife: Sociedade Brasileira de Geologia, 1978, p. 2579-2593.

HASUI, Y; DANTAS, A.S.L; CARNEIRO, C.D.R; BISTRICH, C.A. O embasamento Pré-Cambriano e Eopaleozoico em São Paulo. Mapa Geológico do Estado de São Paulo, Escala 1.500.000. São Paulo, SP, Brasil, v. 1, p. 12-45, 1981.

HEILBRON, M.; VALERIANO, C.M.; VALLADARES, C.S.; MACHADO, N.A Orogênese Brasiliana no segmento central da Faixa Ribeira, Brasil. Revista Brasileira de Geociências, v. 25, n. 4, p. 249-266, 1995.

HEILBRON, M.; PEDROSA-SOARES, A.C.; CAMPOS NETO, M.C.; SILVA, L.C. TROUW, R.A.J.; JANASI, V.A. Província Mantiqueira. In: MANTESSO NETO, V., BARTORELLI, A., CARNEIRO, C.D.R., BRITO-NEVES, B.B. (Eds.) 2004. Geologia do Continente Sul-americano. São Paulo: Ed. Beca, p. 203-236, 2004

INSTITUTO GEOGRÁFIC0 GEOLÓGIC0 (IG). Mapa Geológico do Estado de São Paulo, em 1:1.000,000. São Paulo, 1974.

INSTITUTO GEOGRÁFICO GEOLÓGICO (IG). Mapa geológico do Estado de São Paulo, em 1:1.000.000, São Paulo, 1963.

IRVINE, T.N. \& BARAGAR, W.R.A. A guide to the chemical classification of the common volcanic rocks. Canadian Journal of Earth Sciences, v. 8, p. 523-548, 1971.

JENSEN, L.S. A new cation plot for classifying subalkaline volcanic rocks. Ontario Division of Mines. Misc Paper, v. 66, 22 p., 1976.

LEAKE, B.E.; WOOLEY, A.R.; ARPS, C.E.S.; BIRCH, W.D.; GILBERT, M.C.; GRICE, J.D.; HAWTHORNE, F.C.; KATO, A.; KISCH, H.J.; KRIVOVICHEV, V.G.; LINTHOUT, K.; LAIRD, J., MANDARINO, J.A.; MARESCH, W.V.; NICKEL, E.H.; ROCK, N.M.S.; SCHUMACHER, J.C., SMITH, D.C.; STEPHENSON, N.C.N.; UNGARETTI, L.; WHITTAKER, E.J.W.; YOZHI, G. Nomenclature of amphiboles: Report of Subcommittee on Amphiboles of the International Mineralogical Association. Commission on New Minerals and Mineral Name. American Mineralogist, v. 82, p. 1019-1037, 1997.

MALAGUTTI, M.I.A.; BAHIA FILHO, O.; MORENO, M.M.T.; NARDY, A.J.R. Determinação de elementos terras raras e ítrio em rochas silicáticas por ICP-AES com separação em resina trocadora de íons. Geochimica Brasiliensis, v. 12, n. 1/2, p. 75 80, 1998.

MANIESI, V. Petrologia das rochas anfibolíticas das regiões de Adrianópolis, Campo Largo e Rio Branco do Sul/ PR. Rio Claro, 1997. 215 p. Tese (Doutorado) - Instituto de Geociências, Universidade Paulista.

MANIESI, V. \& OLIVEIRA, M.A.F. Anfibolitos com afinidades dos basaltos de fundo oceânico: regiões de Adrianópolis e Campo Largo/PR. In: CONGRESSO BRASILEIRO DE GEOLOGIA, 40, 1998. Belo Horizonte. Anais...Belo Horizonte: Sociedade Brasileira de Geologia, 1998, p. 456.

MANIESI, V. \& OLIVEIRA, M.A.F. Quimismo mineral e metamorfismo de anfibólios e sua relação com feições texturais nos corpos anfibolíticos de Adrianópolis e Campo Largo/PR. In: CONGRESSO BRASILEIRO DE GEOLOGIA, 39, 1996. Salvador. Anais...Salvador: Sociedade Brasileira de Geologia, 1996. v. 2, p. 138-140.
MANIESI, V. \& OLIVEIRA, M.A.F. Modificações Mineralógicas e Químicas de Metabasitos em Zonas de Cisalhamento das Regiões de Adrianópolis e Campo Largo/PR. Geochimica Brasiliensis, v. 13, n. 2, p. 110-120, 1999

MANIESI, V. \& OLIVEIRA, M.A.F. Metabasitos com afinidades dos basaltos komatíiticos da região de Rio Branco do Sul/PR. Revista Brasileira de Geociências, v. 32, p. 163-168, 2002.

MANIESI, V.; OLIVEIRA, M.A.F.; ZANARDO, A. Petrologia do metagabro de Apiaí. In: SIMPÓSIO DE GEOLOGIA DO SUDESTE, 6, São Pedro, 1999. Boletim de Resumos...São Pedro: Sociedade Brasileira de Geologia, 1999, p. 36

MARINI, O.J.; TREIN, E.; FUCK, R.A. O Grupo Açungui no Estado do Paraná. Boletim Paranaense de Geociências, v. 23/25, p. 43-103, 1967

MELCHER, G.C.; CORDANI, U.G.; DAMASCENO, E.C.; GIRARDT, V.A.V.; GOMES, C.B., LELLI, S.H.S.; MELFI, A.J. Geologia da Folha de Capão Bonito, SP. In: CONGRESSO BRASILEIRO DE GEOLOGIA, 25, 1971, São Paulo. Boletim de Resumos...São Paulo: Sociedade Brasileira de Geologia, 1971, p. 194, 1971

MESCHEDE, M. A method of discriminating between different types of mid-ocean ridge basalts and continental tholeites with the Nb-Zr-Y diagram. Chemical Geology, v. 16, p. 207-218, 1986.

MIDDLEMOST, E.A.K. The Basalt Clan. Earth-Science Reviews, v. 11, p. 337-564, 1975

MIDDLEMOST, E.A.K. Naming Materials in the Magma/Igneous Rock System. Earth-Science Reviews, v. 37, p. 215- 244, 1994.

MULLEN, E.D. MnO/TiO2, P2O5: a minor element discriminant for basaltic rocks of oceanic environments and its implications for petrogenesis. Earth and Planetary Science Letters, v. 62, p. 53-62, 1983.

OLIVEIRA, M.A.F.; MANIESI, V.; TEIXEIRA, W.; DAITX, E.C. Caracterização isotópica de metabasitos e anfibolitos dos grupos Açungui e Setuva na Porção Sul da Faixa Ribeira. Geologia USP. Série Científica, v. 2, p. 161-170, 2002.

OLIVEIRA, M.A.F.; MANIESI, V.; NARDY, A.J.E. Litogeoquímica, química mineral e termobarometria do Metagabro de Apiaí. UNESP-Rio Claro, Geociências, v. 31, n. 4, p. 665-680, 2012

OTTEN, M.T. The origin of brown hornblende in the Artfllet gabbro and dolerites. Contributions to Mineralogy and Petrology, v. 86, p. 189-199, 1984.

PEARCE, J.A. Geochemical fingerprinting of oceanic basalts with applications to ophiolite classification and the search for Archean oceanic crust. Lithos, v. 100, p. 14-48, 2008.

PEARCE, J.A. \& CANN, J.R. Tectonic setting of basic volcanic rocks determined using trace element analyses. Earth and Plan. Sci. Lett., v. 19, n. 290-300, 1973.

PEARCE, J.A. \& NORRY, M.J. Petrogenetic implications of Ti, $\mathrm{Zr}, \mathrm{Y}$ and $\mathrm{Nb}$ variations in volcanic rocks. Contribution Mineral Petrology, v. 69, p. 33-47, 1979.

PEARCE, T.H.; GORMAN, B.E.; BIRKETT, T.C. The relationship between major element geochemistry and tectonic environment of basic and intermediate volcanic rocks. Earth and Planetary Science Letters, v. 36, p. 121-132, 1977.

PERROTTA, M.M.; SALVADOR, E.D.; LOPES, R.C.; D'AGOSTINHO, L.Z.; PERUFFO, N.; GOMES, S.D.; SACHS, L.L.; MEIRA, V.T.; GARCIA, M.G.M.; LACERDA FILHO, J.V. Mapa Geológico do Estado de São Paulo, escala 1:750.000. Programa Geologia do Brasil-PGB, CPRM, São Paulo, 2005.

PONTES, J.B. Investigações e potencialidades econômicas da Formação Água Clara (PR). MINEROPAR, Curitiba, 34 p. 1981.

REIS NETO, J.M. Faixa Itaiacoca: registro de uma colisão entre dois blocos continentais no Neoproterozoico. São Paulo, 1994, 296 p. Tese (Doutorado), Instituto de GeociênciasUniversidade de São Paulo. 
SANTOS, T.M.B.; TASSINARI, C.C.G.; FONSECA, P.E. Diachronic collision, slab break-off and long-term high thermal flux in the Brasiliano -Pan-African orogeny: Implications for the geodynamic evolution of the Mantiqueira Province. Precambrian Research, v. 260, p. 1-22, 2015.

SCHMIDT, M.W. Amphibole composition in tonalite as a function of pressure: An experimental calibration of the AI-inhornblende barometer. Contributions to Mineralogy and Petrology, v. 110, p. 304-310, 1992.

SHERVAIS, J.W. Ti-V plots and the petrogenesis of modern and ophiolite lavas. Earth and Planetary Science Letters, v. 59, n. 1, p. 101-118, 1982.

SIGA JR.; BASEI, M.A.S.; SATO, K.; PRAZERES FILHO, H.J.; CURY, L.F.; WEBER, W.; PASSARELLI, C.R.; HARARA, O.M.; REIS NETO, J.M. U-Pb (Zircon) Ages of Metavolcanic Rocks from the Itaiacoca Group: Tectonic Implications. Geol. USP Série Científica, São Paulo, v. 3, p. 39-49, 2003

SILVA, M.J. \& VASCONCELLOS, E.M.G. Estudo geoquímico das rochas metabásicas da faixa de dobramentos Apiaí. In: CONGRESSO DE GEOQUÍMICA DOS PAÍSES DE LÍNGUA PORTUGUESA, V e CONGRESSO BRASILEIRO DE GEOQUÍMICA, VII, 1999. Porto Seguro. Anais...Porto Seguro: Sociedade Brasileira de Geoquímica, 1999, p. 592-595.

TAKAHASHI, A.T.; FERREIRA, J.C.G.; THEODOROVICZ, A.; BATOLlA JUNIOR, F., CHIODI FILHO, C. Mapa Geológico da Folha Guapiara (SG.22-X-B-II-2). SUREGSP. Relatório Final, 130 p., 1984.

TASSINARI, C.C.G. As Idades das Rochas e dos Eventos Metamórficos da Porção SE do Estado de São Paulo e sua Evolução Crustal. São Paulo, 1988. 236p. Tese (Doutorado), Instituto de Geociências - Universidade de São Paulo.

TASSINARI, C.C.G.; BARBOUR, A.P.; DAITX, E.C.; SATO. K. Aplicação dos isótopos de $\mathrm{Pb}-\mathrm{Sr}$ na determinação da natureza das fontes das mineralizações de chumbo do Vale do Ribeira - SP e PR. In: CONGRESSO BRASILEIRO DE GEOLOGIA, 36, 1990, Natal. Anais...Natal: Sociedade Brasileira de Geologia, n. 3, p. 1254-1266, 1990.

THEODOROVICZ, A; CÂMARA, M.M.; MORAES, S.M.; GODOY, H.K.; TAKAHASHI, A.T. Projeto Engenheiro MaiaRibeirão Branco: Relatório Final. São Paulo. Contrato CPRM/PROMINÉRIO. 2v., 1986.
THEODOROVICZ, A.; CÂMARA, M.M.; TAKAHASHI, A.T.; MORAES, S.M.; GODOY, H.K. Geologia do Pré-Cambriano das Folhas Engenheiro, Maia e Ribeirão Branco, São Paulo. In: CONGRESSO BRASILEIRO DE GEOLOGIA, 35, Belém, 1988. Anais...Belém: Sociedade Brasileira de Geologia, 1988 , v. 6 , p. 2713-2726.

VIEIRA, O.A.R.P. Geologia da Folha Guapiara 1:50.000 (SG22-X-B-II-2). Rio Claro, 2017. 145 p. Dissertação (Mestrado), Instituto de Geociências e Ciências Exatas-Universidade Estadual Paulista.

VIEIRA, O.A.R.P.; GODOY, A.M.; HACKSPACHER, P.C.; LEITE JUNIOR, W.B. Contexto Estrutural da Área da Folha Topográfica Guapiara. São Paulo, UNESP, Geociências, v. 37, n. 3, p. 505-521, 2018a.

VIEIRA, O.A.R.P.; GODOY, A.M.; LEITE JUNIOR, W.B.; HACKSPACHER, P.C. Geologia da Folha Topográfica Guapiara na escala 1:50.000. São Paulo, UNESP, Geociências, v. 37, n. 2, p. 263-277, 2018b.

WEAVER, B. \& TARNEY, J. Empirical approach to estimating the composition of the continental crust. Nature, v. 310, p. 57557, 1984.

WEBER, W. Geocronologia de rochas metabásicas da Formação Água Clara: Registro de uma bacia mesoproterozoica. São Paulo, 2004. Tese (Doutoramento), Instituto de Geociências - Universidade de São Paulo.

WEBER, W.; SIGA JR, O.; BASEI, M.A.S.; SATO, K. A Formação Água Clara na Região de Araçaíba -SP, Registro de uma bacia Mesoproterozoica. In: CONGRESSO BRASILEIRO DE GEOLOGIA, 41, 2002. João Pessoa. Anais...João Pessoa: Sociedade Brasileira de Geologia, 2002, p. 346.

WEBER, W.; SIGA JR, O.; SATO, K.; REIS NETO, J.M.; BASEI, M.A.S.; NUTMAN, A.P. A Formação Água Clara na região de Araçaíba-SP: registro de uma bacia mesoproterozoica. Geologia USP, Série Científica, v. 4, p. 101-110, 2004 